\title{
New records of Philometra spp. (Nematoda: Philometridae) from marine perciform fishes off Florida, USA, including descriptions of two new species
}

\author{
František Moravec $^{1}$, Micah D. Bakenhaster ${ }^{2}$ and Theodore S. Switzer ${ }^{2}$ \\ ${ }^{1}$ Institute of Parasitology, Biology Centre of the Czech Academy of Sciences, České Budějovice, Czech Republic; \\ ${ }^{2}$ Fish and Wildlife Research Institute, Florida Fish and Wildlife Conservation Commission, St. Petersburg, Florida, USA
}

\begin{abstract}
Recent examinations of marine perciform fishes from off the Florida coast in the Gulf of Mexico and Straits of Florida, USA, revealed the presence of the following six species of Philometra Costa, 1845 (Nematoda: Philometridae): P. haemulontis sp. n. (males and females) from the ovary of Haemulon plumierii (Lacepède) (type host) and H. aurolineatum Cuvier (both Haemulidae); Philometra synagridis Moravec, Bakenhaster et Fajer-Ávila, 2014 (males and females) from the ovary and testes of Lutjanus synagris (Linnaeus) (Lutjanidae); P. margolisi Moravec, Vidal-Martínez et Aguirre-Macedo, 1995 (male) from the ovary of Hyporthodus nigritus (Holbrook) (Serranidae) (new host record; probably a paradefinitive host); P. andersoni sp. n. (male) from the ovary of H. nigritus; Philometra sp. 1 (male) from the ovary of Rhomboplites aurorubens (Cuvier) (Lutjanidae); and Philometra sp. 2 (females) from the subcutaneous tissue of the anterior-most head sinuses of Hyporthodus niveatus (Valenciennes) (Serranidae). Specimens of species are described and illustrated based on light and (except for Philometra sp. 1) scanning electron microscopical examinations. Philometra haemulontis sp. n. differs from all congeners in the unique structure of the gubernaculum, whereas $P$. andersoni sp. n. can be differentiated from other gonad-infecting congeners parasitising the Serranidae by a combination of morphological features. Females of $P$. synagridis are described for the first time. Gravid females of Philometra sp. 2 are similar to those of P. morii Moravec, Bakenhaster et Fajer-Ávila, 2010, a subcutaneous parasite of Epinephelus morio (Valenciennes) (Serranidae) in the Gulf of Mexico.
\end{abstract}

Keywords: Parasitic nematode, Dracunculoidea, Perciformes, Gulf of Mexico, Warsaw Hole, Florida Keys, Special Management Zones (SMZ), Straits of Florida, North America, biodiversity

Nematodes of the dracunculoid family Philometridae Baylis et Daubney, 1926 are characterised by some specific morphological features such as the absence of the anus and vulva in gravid females and the presence of a movable gubernaculum in males. They are further characterised by biological peculiarities including mainly their life-cycle patterns and the location of adults in various tissues and body cavities of the host. They are a large, diverse group of parasites of teleost fishes, and the species collectively have a worldwide distribution. Individual species of philometrids occur in freshwater, brackish-water or marine fishes and are characterised by the site of infection in the host; they typically exhibit a high degree of host specificity (Moravec and de Buron 2013, Moravec et al. 2014, 2016a,b).

To date, 22 nominal species of Philometra Costa, 1845 are known to parasitise marine and brackish-water fishes in the region of the North-West Atlantic Ocean, including the Gulf of Mexico (e.g., Moravec 2006, Moravec et al. 2016b). Of these, most species are known from relatively well-studied, mostly economically important host species representing Serranidae (9), Lutjanidae (4) and Sciaenidae (3), whereas only one species of the Philometra has been described from each of the Exocoetidae, Malacanthidae, Muraenidae, Paralichthyidae, Pomatomidae and Scombridae. During recent helminthological investigations of some serranid, lutjanid and haemulid fishes off the Florida coast, USA, several representatives of Philometra, including two new species, were recorded. These are described below.

\section{MATERIALS AND METHODS}

Fish were collected by the Florida Fish and Wildlife Conservation's Fish and Wildlife Research Institute (FWRI) during fish population studies in the Gulf of Mexico or as part of a collaborative effort with the South Atlantic Fishery Management Council and the Pew Charitable Trusts to survey fish populations in the Warsaw Hole Special Management Zone (SAFMC 2020) located southwest of the Marquesas Keys (Fig. 1). In the Gulf of Mexico, sampling was conducted aboard chartered research vessels (R/V Tommy Munro, University of Southern Mississippi, and R/V W.T. Hogarth, University of South Florida), and fishing 


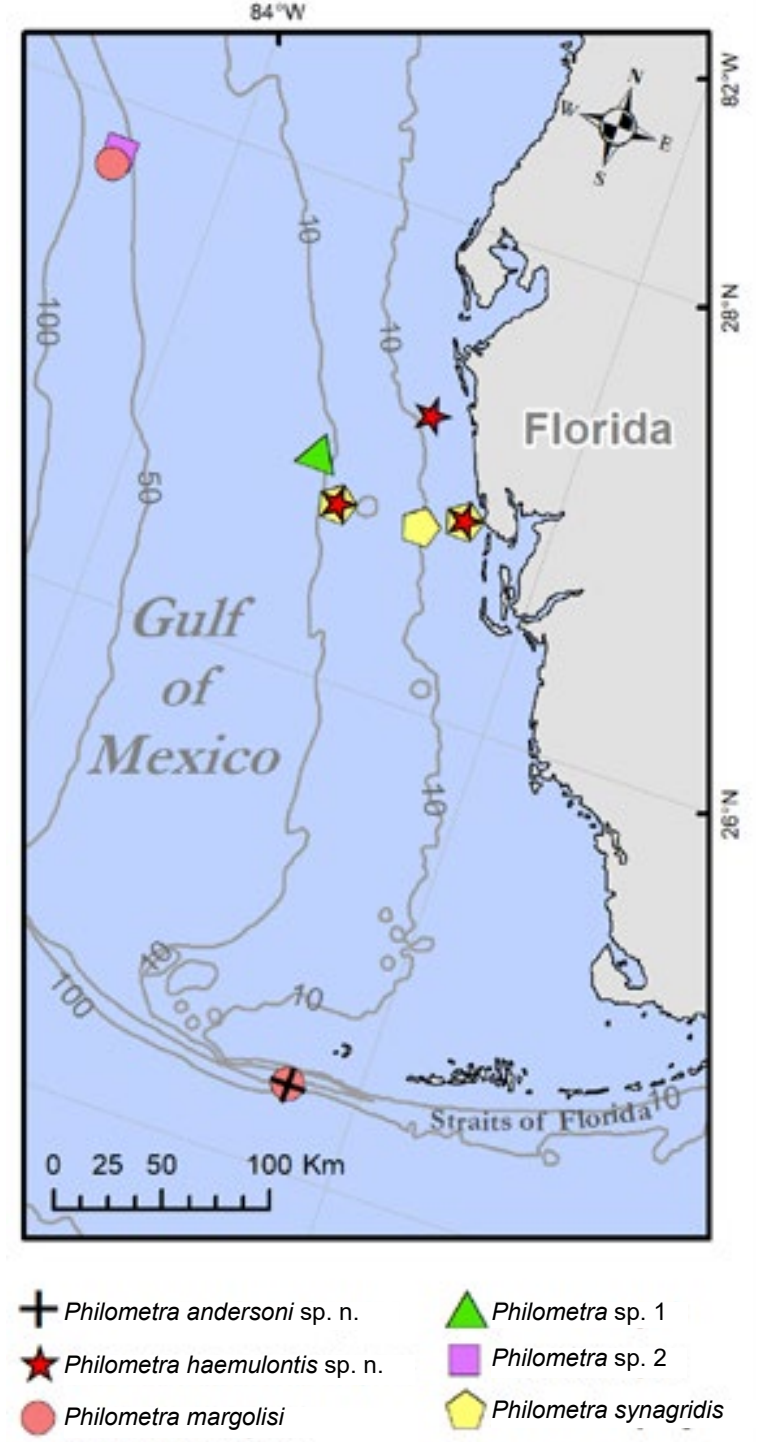

Fig. 1. Map of study area identifying sampling stations where the parasitic nematodes were collected.

gears included hook and line, trawl and traps. Fishing at Warsaw Hole and the Sticky Grounds was by hook and line and was conducted aboard a chartered, for-hire fishing vessel (F/V See-Ya and F/V Lagerhead, respectively). All fish were placed immediately on ice after capture, then measured for standard length (SL) and examined for parasites within 24 hours. Processing of fresh hosts was conducted in shipboard laboratories or after transport to the FWRI South Florida Regional Laboratory in Marathon, Florida. Global Positioning System coordinates were determined with shipboard or handheld GPS devices, and measurements of distance provided were determined with the Google Earth Pro application (version 7.3.2). Coordinates for fish collected in trawls were the starting point of east to west tows over approximately $1 \mathrm{~km}$ of bottom.

Philometrids used for morphological studies were collected alive and heat-killed by dousing with hot tap water $\left(70-80^{\circ} \mathrm{C}\right)$. Fixation was with $5 \%$ formalin, derived from the addition of $10 \%$ neutral buffered formalin to the hot water to double the volume of fluid. In some cases, nematodes were heat-killed and fixed in situ with the host gonad, then later isolated at the main FWRI laboratory in St. Petersburg, FL. however, this method increased the probability of fragmentation of specimens, so whenever practicable, nematodes were isolated from host tissues while still alive prior to heat-fixation. Individuals of gonad-infecting species were isolated with forceps and fine paintbrushes (grossly visible females) or under a dissecting microscope from saline rinsings of slit ovaries or testes torn apart with forceps to free the minute males. Subcutaneous nematodes, all females, were detected grossly after dissection of the host's upper jaw and head sinuses with heavy pruning shears. Thereafter, they were carefully teased from host tissues with fine forceps. Unsuccessful attempts were made to locate subcutaneous males in seawater rinsings of torn tissue from the vicinity of the female worms. All isolated and fixed nematode specimens were shipped to the Institute of Parasitology, Biology Centre of the Czech Academy of Sciences in České Budějovice, Czech Republic for further processing. In a few cases when nematodes were sufficiently numerous, representative specimens were placed directly in $95 \%$ ethanol to be processed for DNA sequencing at the FWRI laboratory, but those data are not presented here, pending collection of additional material to ensure meaningful results.

For light microscopical examination, the nematodes were cleared with glycerine. Drawings were made with the aid of a Zeiss drawing attachment. Specimens used for scanning electron microscopy (SEM) were postfixed in $1 \%$ osmium tetroxide (in phosphate buffer), dehydrated through a graded acetone series, critical-point-dried and sputter-coated with gold; they were examined using a JEOL JSM-7401F scanning electron microscope at an accelerating voltage of $4 \mathrm{kV}$ (GB low mode). All measurements are in micrometres unless otherwise indicated. The type and voucher specimens have been deposited in the Smithsonian National Museum of Natural History, Washington, USA (SNMNH) and in the Helminthological Collection of the Institute of Parasitology, Biology Centre of the Academy of Sciences, České Budějovice, Czech Republic (IPCAS). The fish nomenclature adopted follows FishBase (Froese and Pauly 2020).

\section{RESULTS}

\section{Philometridae Baylis et Daubney, 1926}

\section{Philometra haemulontis sp. n.}

Figs. 2-5

ZooBank number for species:

urn:Isid:zoobank.org:act:A8226C02-D2CB-43A4-B9CF-00E91B7C02F4

Male (16 specimens from Haemulon plumierii; measurements of holotype in parentheses. Measurements of 1 specimen from Haemulon aurolineatum Cuvier in brackets): Body filiform, whitish, 2.23-2.86 (2.80) [3.36] mm long, maximum width at middle of body 63-90 (78) [87]; anterior part of body tapering to anterior extremity, without usual constriction just posterior to cephalic end (Fig. 2E). Maximum width/body length ratio $1: 29-39$ (1:36) [1:39]. Cuticle smooth or partly with fine transverse striations. Cephalic end rounded, 18-24 (21) [21] wide. Oral aperture small, oval, surrounded by narrow ring of elevated cuticle. Cephalic papillae 14 in number, arranged in 2 

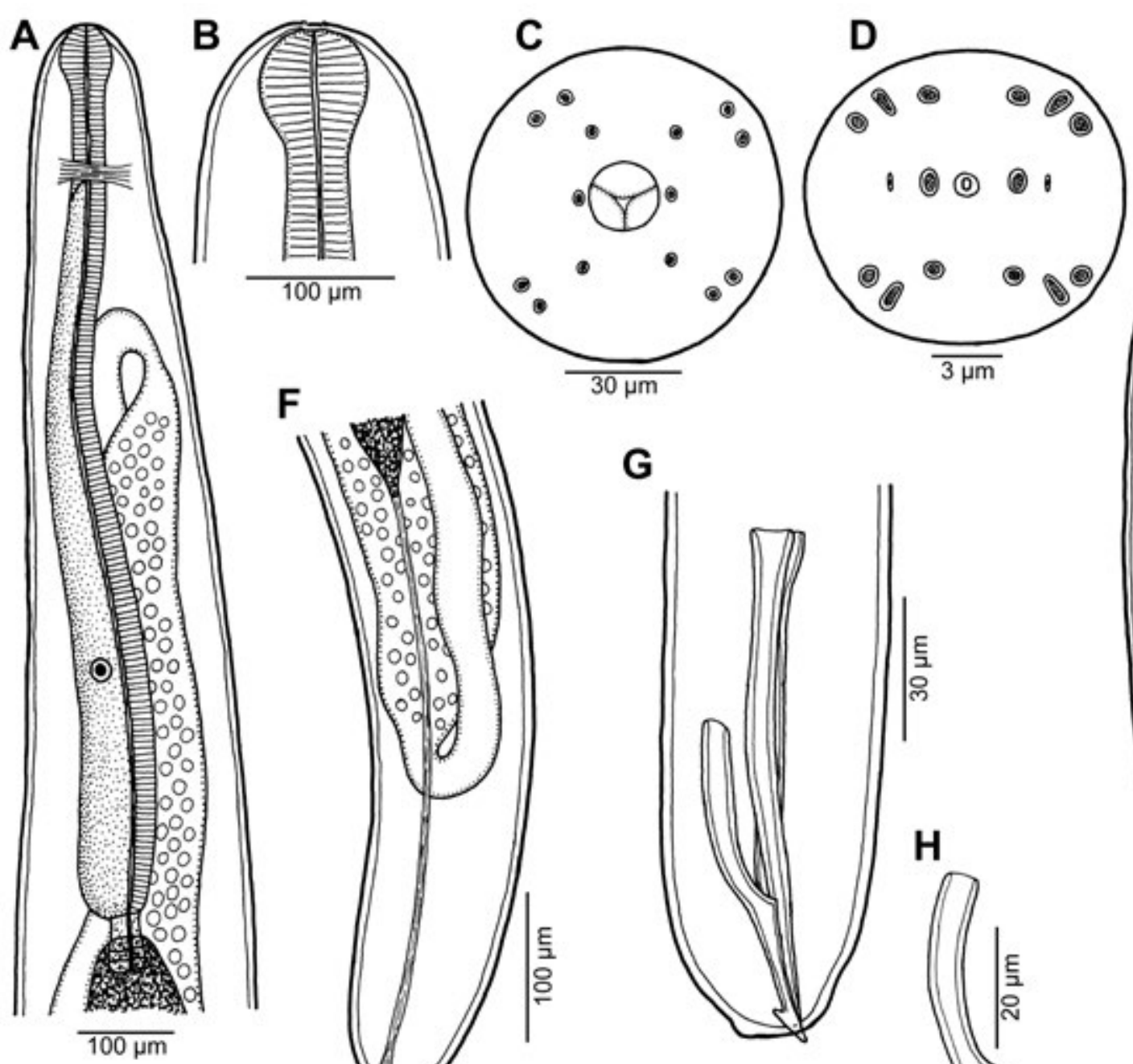

E

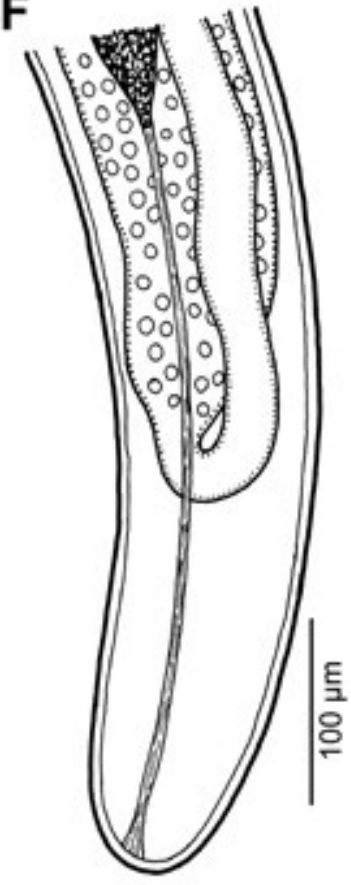

G

$\mathbf{K}$
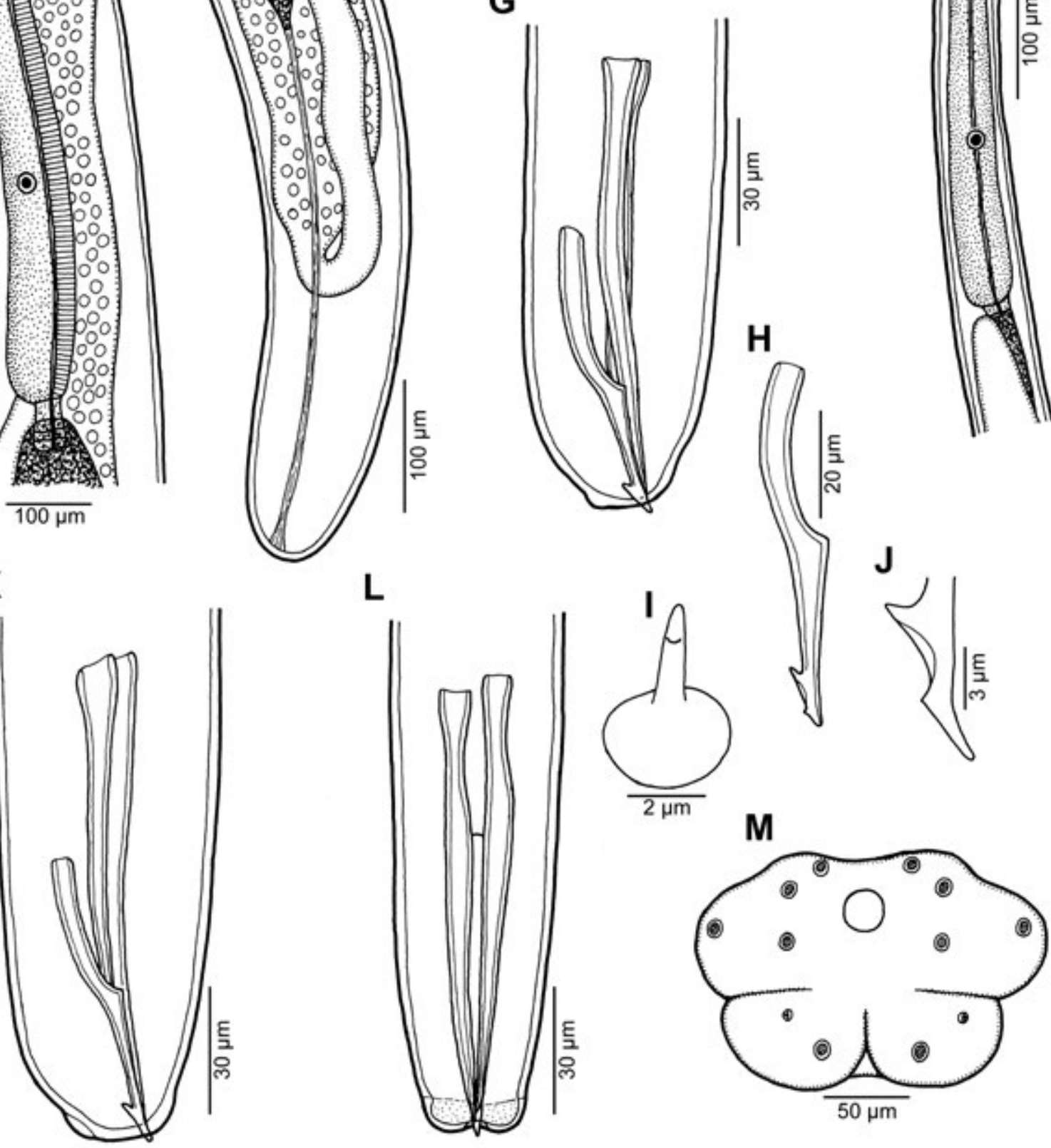

Fig. 2. Philometra haemulontis sp. n. from the ovary of Haemulon plumierii (Lacepède). $\mathbf{A}$ - anterior end of subgravid female, lateral view; B, C - cephalic end of subgravid female, lateral and apical views, respectively; $\mathbf{D}$ - cephalic end of male, apical view; $\mathbf{E}$ - anterior end of male, lateral view; $\mathbf{F}$ - posterior end of subgravid female, lateral view; $\mathbf{G}$ - posterior end of male, lateral view; $\mathbf{H}$ - gubernaculum, lateral view; $\mathbf{I}, \mathbf{J}$ - distal end of gubernaculum, subapical and lateral views, respectively; $\mathbf{K}, \mathbf{L}-$ posterior end of male (another specimen), lateral and ventral views, respectively; $\mathbf{M}$ - caudal end of male, apical view. 

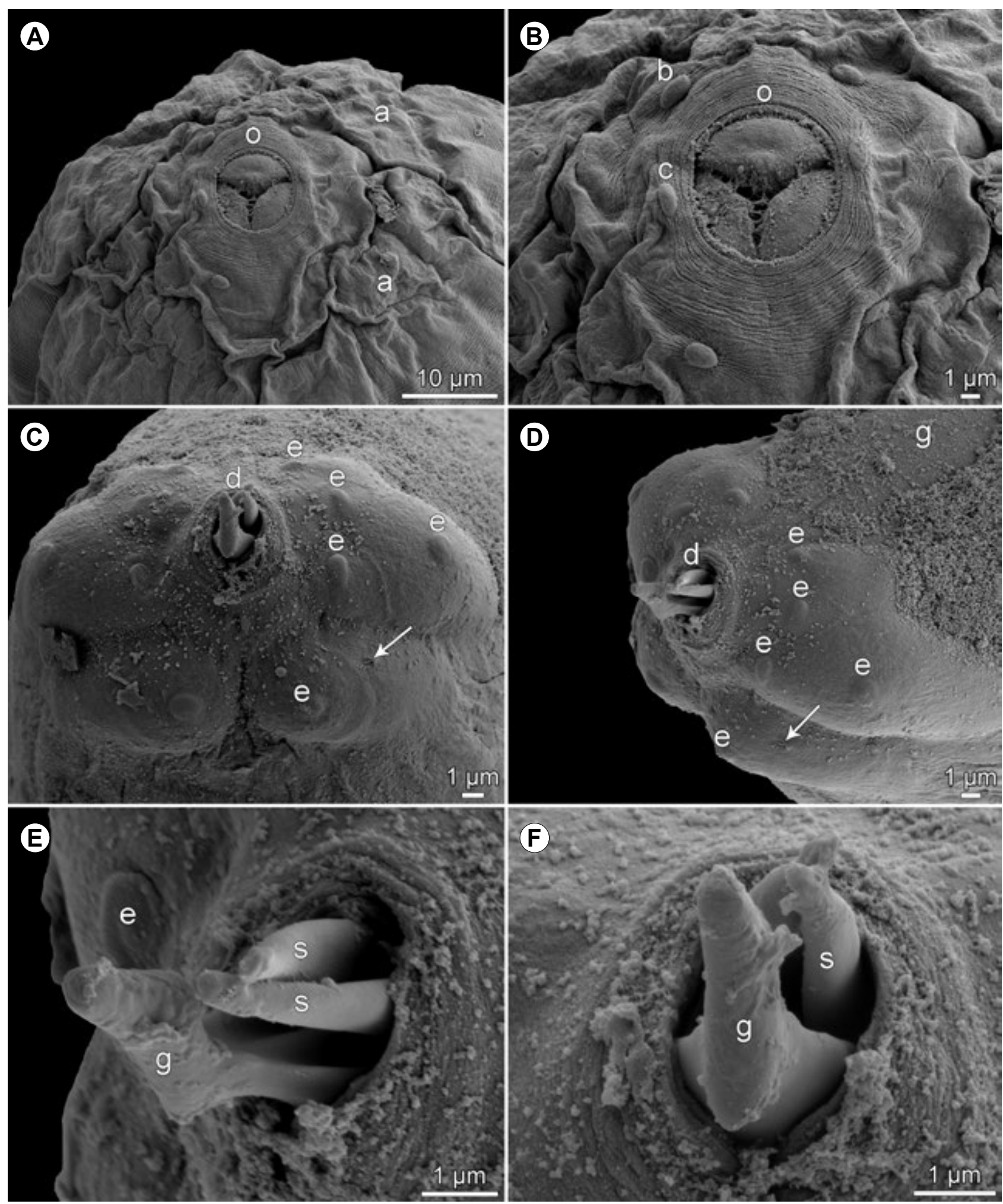

Fig. 3. Philometra haemulontis sp. $\mathrm{n}$. from the ovary of Haemulon plumierii (Lacepède), scanning electron micrographs. A - cephalic end of subgravid female, apical view; $\mathbf{B}$ - region of mouth of subgravid female, apical view; $\mathbf{C}, \mathbf{D}$ - caudal end of male, apical and sublateral views, respectively (arrows indicate phasmid); E, F - region of male cloacal aperture, sublateral and apical views, respectively. Abbreviations: a - submedian pair of outer cephalic papillae; $\mathrm{b}$ - submedian cephalic papilla of inner circle; $\mathrm{c}$ - lateral cephalic papilla of inner circle; $\mathrm{d}$ - cloacal aperture; $\mathrm{e}$ - caudal papilla; $\mathrm{g}$ - gubernaculum; $\mathrm{o}$ - oral aperture; $\mathrm{s}$ - spicule. 

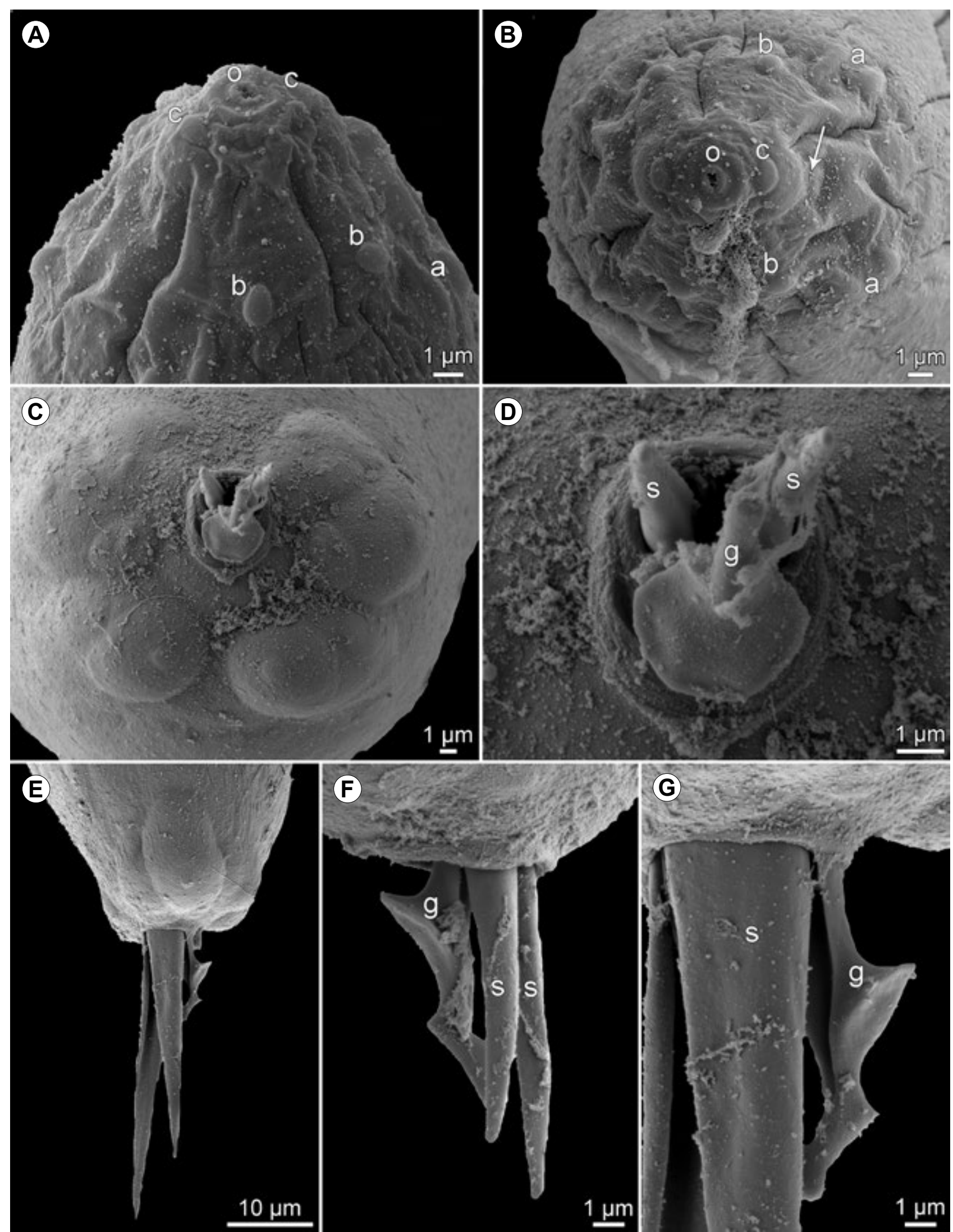

Fig. 4. Philometra haemulontis sp. $\mathrm{n}$. from the ovary of Haemulon plumierii (Lacepède), scanning electron micrographs of male. A - cephalic end, dorsoventral view; B - cephalic end, apical view (arrow indicates amphid); $\mathbf{C}$ - caudal end with protruding distal tip of gubernaculum, apical view; D - region of cloaca with protruding distal tip of gubernaculum, apical view; $\mathbf{E}$ - caudal end with protruding distal ends of spicules and gubernaculum, lateral view; $\mathbf{F}$ - distal end of gubernaculum, lateral view; $\mathbf{G}$ - distal end of gubernaculum (enlarged), sublateral view. Abbreviations: a - submedian pair of outer cephalic papillae; $b$ - submedian cephalic papilla of inner circle; $\mathrm{c}$ - lateral cephalic papilla of inner circle; $\mathrm{g}$ - gubernaculum; o - oral aperture; $\mathrm{s}$ - spicule. 
circles; outer circle formed by 4 submedian pairs, inner circle consists of 4 submedian and 2 lateral papillae (Figs. 2D, 4A,B, 5A). Pair of small, slit-like lateral amphids somewhat posterior to lateral cephalic papillae (Figs. 2D, 4B). Oesophagus 465-885 (510) [471] long, comprising $17-40 \%$ (18\%) [14\%] of body length, with slight inflation at anterior end measuring $18-42 \times 12-15(24 \times 15)[21 \times$ $15]$; posterior part of muscular oesophagus overlapped by well-developed oesophageal gland with large cell nucleus; maximum width of gland 24-45 (30) [27]. Ventriculus small, 6-9 (9) [9] long, 15-33 (18) [18] wide. Nerve ring and oesophageal nucleus 141-186 (186) [186] and 369582 (390) [378], respectively, from anterior extremity. Excretory pore 171-219 (219) [222] from anterior end.

Testis extending anteriorly approximately to level of posterior end of oesophagus (Fig. 2E). Posterior end of body blunt, 24-39 (30) [33] wide, with broad caudal mound formed by 2 lateral lobes, each lobe comprising a set of 3 distinct lobules, dorsolateral lobules within each set well separated from lateral lobules, lobes well separated dorsally and separated by and nearly abbuting cloacal aperture ventrally (Figs. 2M, 3C,D, 4C,E). Five pairs of small caudal papillae present: 4 pairs (1 subventral preanal and 3 [2 subventral and 1 lateral] adanal) situated on ventrolateral lobules of caudal mound and 1 subventral postanal pair on dorsolateral lobules; pair of small phasmids present somewhat anterior to postanal papillae on dorsolateral lobules of mound (Figs. 2M, 3C,D, 4C,E, 5B-D).

Spicules needle-like, equal or slightly unequal in length, with somewhat expanded proximal and sharply pointed distal tips (Figs. $2 \mathrm{G}, \mathrm{K}, \mathrm{L}, 4 \mathrm{E}, 5 \mathrm{~B}, \mathrm{C}$ ); length of left spicule 117-129 (126) [117], representing 4.2-5.4\% (4.5\%) [3.5\%] of body length, of right spicule 117-123 (117) [117]; length ratio of spicules $1: 1.00-1.10$ (1:1.08) [1 : 1.00]. Gubernaculum narrow, 69-84 (75) [60] long, with anterior portion somewhat dorsally bent; length of anterior bent part 27-45 (42) [27], representing 39-67\% $(56 \%)$ [45\%] of entire gubernaculum length (Fig. $2 \mathrm{G}-\mathrm{K})$; distal tip of gubernaculum somewhat rounded, smooth, appearing to have 2 distinct reflexed dorsal barbs (1 large and 1 more distal small barb) in lateral view (Figs. 2H-J, 3E,F, $4 \mathrm{~F}, \mathrm{G})$, but "large barb" represents in fact dorsal and lateral gubernaculum extension forming conspicuous platelike structure in apical view (Figs. 2I, 3F, 4C,D); ventral surface of this part of gubernaculum with 2 longitudinal grooves (Figs. 3E, 4G). Length ratio of gubernaculum and left spicule $1: 1.39-1.83$ (1:1.68) [1:1.95]. Spicules and gubernaculum well sclerotised, yellowish, anterior part of gubernaculum and proximal ends of spicules colourless.

Subgravid female ( 7 ovigerous specimens; measurements of allotype in parentheses): Body of fixed specimens brownish; anterior and posterior parts of body tapered, with rounded ends. Cuticle smooth. Body length 78-110 (110) mm, maximum width 476-734 (503); maximum width/body length ratio 1 : 137-219 (1:219). Width of cephalic end 109-190 (190). Cephalic papillae small, indistinct when laterally viewed (Fig. 2A,B). Oral aperture almost circular, surrounded by small cephalic papillae arranged in 2 circles and slightly outlined amphids; inner circle of papillae consists of 4 submedian and 2 lateral single papillae, outer circle formed by 4 submedian pairs of papillae (Figs. 2C, 3A,B). Oesophagus including well-developed anterior bulbous inflation 1.09-1.43 (1.43) mm long, comprising $1.1-1.5 \%(1.3 \%)$ of body length; anterior inflation 78-99 (99) long and 60-75 (75) wide; maximum width of posterior part of oesophagus including gland 68-122 (95). Oesophageal gland well developed, opening into oesophagus just posterior to nerve ring, with large cell nucleus at middle (Fig. 2A). Nerve ring and oesophageal nucleus 258-367 (367) and 762-1,034 (1,034), respectively, from anterior extremity. Ventriculus small, 33-48 (48) long, 54-81 (75) wide. Intestine brown, straight, ending blindly; posterior end of intestine atrophied, forming ligament 476-1,224 $(1,061)$ long attached ventrally to body wall close to posterior extremity (Fig. 2F). Vulva and anus absent. Ovaries reflexed near body ends (Fig. 2A,F). Uterus occupying most space of body, filled with numerous eggs (Fig. 2A,F). Posterior end rounded, 136-177 (177) wide, without caudal projections (Fig. $2 \mathrm{~F}$ ).

Nongravid female (1 specimen without eggs): Body whitish, $13.10 \mathrm{~mm}$ long, maximum width 231; maximum width/body length ratio $1: 57$. Width of cephalic end 54 . Oesophagus including anterior bulbous inflation 734 long, comprising $5.6 \%$ of body length; its anterior inflation 57 long and 51 wide. Nerve ring and oesophageal nucleus 190 and 585, respectively, from anterior extremity. Ventriculus 6 long, 18 wide. Intestinal ligament 245 long. Vulva and anus absent. Uterus empty. Posterior end rounded, 82 wide, without caudal projections.

Type host: White grunt Haemulon plumierii (Lacepède) (Haemulidae, Perciformes); 177-215 mm standard length (SL).

Other host: Tomtate grunt Haemulon aurolineatum Cuvier (Haemulidae, Perciformes); $180 \mathrm{~mm} \mathrm{SL}$

Site of infection: Ovary.

Type locality: Gulf of Mexico, West Florida Shelf approximately $10 \mathrm{~km}$ due west of Little Gasparilla Island, Florida, 26.83318, -82.41052, USA (collected 16 April 2017).

Other localities: H. plumierii: Gulf of Mexico, West Florida Shelf approximately $20 \mathrm{~km}$ due west of Osprey, Florida, 27.20013, -82.71983 (collected 13 April 2018). H. aurolineatum: Gulf of Mexico, West Florida Shelf approximately 70 $\mathrm{km}$ due west of Boca Grande, Florida, 26.72535, -82.99491 (collected 17 July 2018).

Prevalence and intensity: For $H$. plumierii, as determined by macroscopic observation, $50 \%$ overall ( 3 infected $/ 6$ examined) and $75 \%$ for female hosts ( 3 infected of 4 examined). For H. aurolineatum (determined from evaluation of gonad risings under a dissecting microscope) $5 \%$ (1 infected of 19 examined [8 female hosts and 11 males]); exact infection intensity was not reliably determinable because some nematodes were fragmented during processing, but maximum intensity was greater than 17 for female nematodes while no more than 2 males were found in a single host.

Deposition of type specimens: SNMNH USNM 1616439-1616442 (male holotype, female allotype and several paratypes); IPCAS N-1209 (several paratypes).

Etymology: The specific name of this nematode relates to the genitive form of the generic name of the host. 

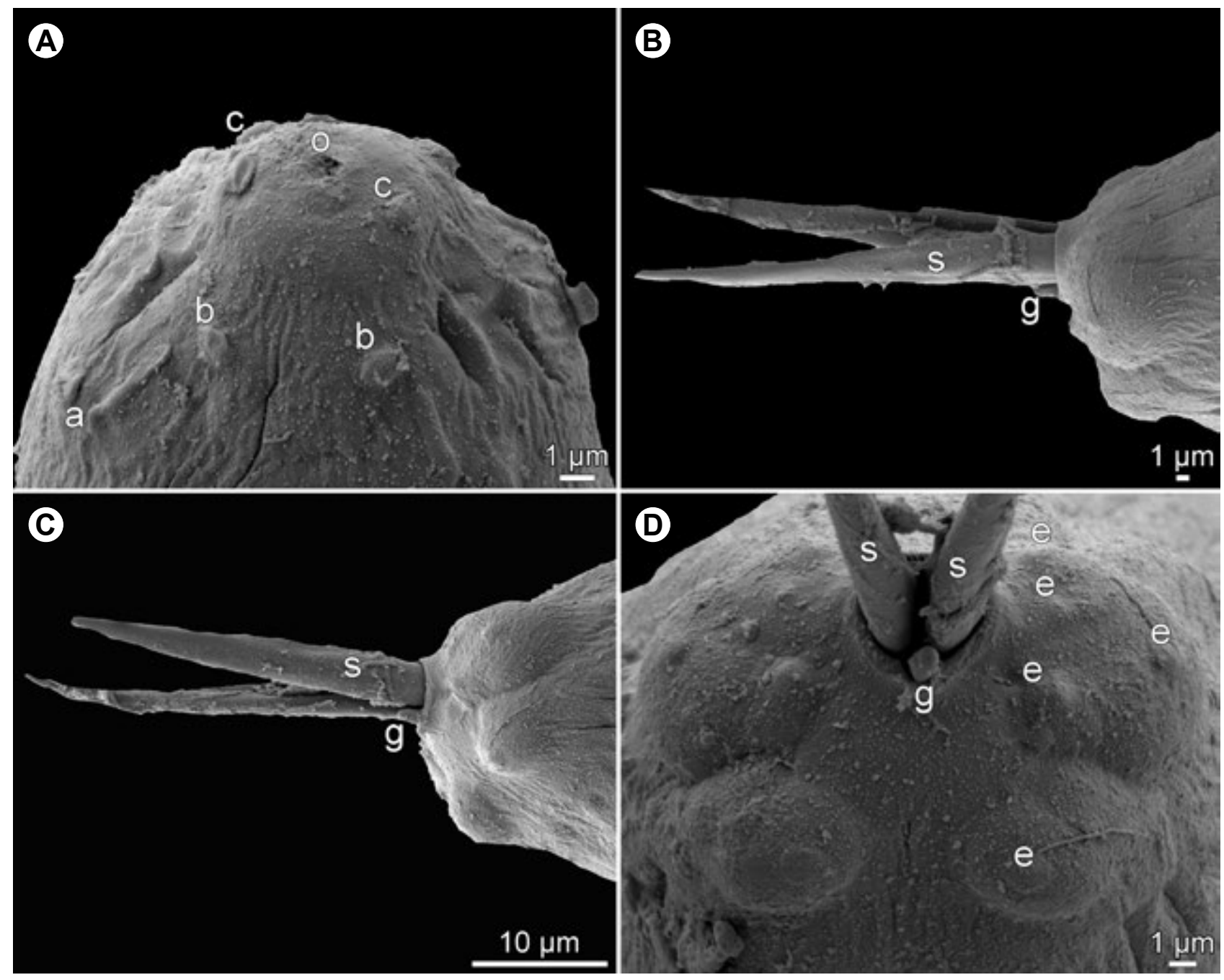

Fig. 5. Philometra haemulontis sp. $\mathrm{n}$. from the ovary of Haemulon aurolineatum Cuvier, scanning electron micrographs of male. $\mathbf{A}$ - cephalic end, dorsoventral view; B, C - caudal end with protruding spicules and gubernaculum, lateral and dorsolateral views, respectively; D - caudal end, apical view. Abbreviations: a - submedian pair of outer cephalic papillae; $\mathrm{b}$ - submedian cephalic papilla of inner circle; $\mathrm{c}$ - lateral cephalic papilla of inner circle; $\mathrm{e}$ - caudal papilla; $\mathrm{g}$ - gubernaculum; $\mathrm{o}$ - oral aperture; $\mathrm{s}$ - spicule.

Remarks. Gonad-infecting species of Philometra exhibit a high degree of host specificity (Moravec and Manoharan 2014a,b, Moravec et al. 2014, 2016a,c, Moravec and Barton 2018). Originally the only nominal species of these parasites reported from the perciform family Haemulidae was P. lateolabracis (Yamaguti, 1935) in Parapristipoma trilineatum (Thunberg) off Japan (Yamaguti 1935) and $H$. plumierii from off the Atlantic coast of Brazil (Crisp and Klein 1973). However, subsequently Quiazon et al. (2008) described, for the first time, the male of $P$. lateolabracis from its type host Lateolabrax japonicus (Cuvier) (Lateolabracidae) and established a new species, P. isaki Quiazon, Yoshinaga et Ogawa, 2008, for nematodes from the ovary of $P$. trilineatum, originally considered by Yamaguti (1935) to be conspecific with P. lateolabracis.

According to Quiazon et al. (2008), the poorly preserved and inadequately described philometrids (including the only available damaged male) from the ovary of $H$. plumierii reported by Crisp and Klein (1973) as P. lateolabracis were in fact misidentified, being morphologically different from both $P$. lateolabracis and $P$. isaki. Taking into account the unreliable description of these nematodes from Brazil, the host species, infection site and the fact that they were collected in the western Atlantic Ocean, it is almost sure that they belonged to $P$. haemulontis. An additional species of Philometra from Haemulidae, P. barnesi Moravec et Diggles, 2015, has been described from the ovary of Pomadasys argenteus (Forsskål) off the northern coast of Australia (Moravec and Diggles 2015).

In many morphological features, $P$. haemulontis is similar to two above-mentioned species parasitising fishes of the family Haemulidae, $P$. barnesi and $P$. isaki. However, in contrast to the new species, no dorsal barbs were observed or reported on the gubernaculum of $P$. barnesi and $P$. isaki and the shape of the anterior body end of males is different (anterior end somewhat narrowed just posterior to the cephalic end to form a "neck" vs anterior body end tapering towards the cephalic end without a "neck").

Moreover, the male of P. barnesi is smaller (length 1.67 $\mathrm{mm}$ vs 2.23-2.86 mm) and its oesophagus, spicules and gubernaculum are distinctly shorter $(297 \mathrm{~m} \mu$ vs 465-885 $\mathrm{m} \mu$, 87/84 $\mathrm{m} \mu$ vs 117-129/117-123 $\mathrm{m} \mu$ and $60 \mathrm{~m} \mu$ vs 69-84 $\mathrm{m \mu}$, 
respectively). Although the male body length $(2.62 \mathrm{~mm})$ and the lengths of spicules (107-127/105-122 $\mathrm{m \mu}$ ) and the gubernaculum $(70-90 \mathrm{~m} \mu)$ of $P$. isaki are approximately the same as those in $P$. haemulontis, the male oesophagus of the former species is considerably shorter $(246-308 \mathrm{~m} \mu$ vs 465-885 mu). In addition, $P$. haemulontis and $P$. isaki differ in their host species, which belong to different genera (Haemulon Cuvier vs Parapristipoma Bleeker or Pomadasys Lacépède) and have strongly allopatric distribution (West Atlantic Ocean vs Indo-West Pacific Ocean).

While the great majority of gonad-infecting species of Philometra, including $P$. lateolabracis, possess the gubernaculum provided with numerous dorsal and lateral transverse lamellar structures at its distal portion (e.g., Quiazon et al. 2008, Moravec and Manoharan 2014a,b, 2016, Moravec et al. 2016a-c, Moravec and Barton 2018), P. haemulontis sp. $\mathrm{n}$. is characterised by the smooth gubernaculum without such structures, that, in lateral view, bears two (one large and one small, more distally situated) reflexed dorsal barbs on its distal tip.

The only other gonad-infecting species of Philometra parasitising marine fishes, in which the gubernaculum is provided with two dorsal barbs, is $P$. atlantica Moravec, Bakenhaster et de Buron, 2013, a parasite of Scomberomorus maculatus (Mitchill) (Scombridae) from off the Atlantic coast of the USA (Moravec et al. 2013). Two dorsal barbs on the gubernaculum have also been reported for two species of Palaearctic philometrids, Philometra rischta Skryabin, 1923 and Philometroides cyprini (Ishii, 1931) (reported as $P$. lusii), both parasites of subcutaneous tissues of freshwater cyprinids (Sokolov and Kazakov 2007, 2008).

However, in contrast to $P$. haemulontis, the barbs on the gubernaculum in all these three species ( $P$. atlantica, $P$. rischta and $P$. cyprini) are simple, without any marked lateral extensions. Therefore, the conspicuous plate-like extension on the gubernaculum of $P$. haemulontis, appearing as a large reflexed dorsal barb in lateral view, is a unique feature among all philometrids.

The presence of one dorsal reflexed barb on a smooth gubernaculum is typical of most Philometra spp. parasitising Holarctic freshwater fishes and also of some North American brackish-water fishes (Moravec 2006, Moravec and de Buron 2013). Among North American species of Philometra, a single dorsal barb has also been reported on the gubernaculum of gonad-infecting $P$. carolinensis Moravec, de Buron et Roumillat, 2006 and P. floridensis Moravec, Fajer-Ávila et Bakenhaster, 2010, both parasites of estuarine-dependent sciaenids, and in three species parasitising the host's abdominal cavity: 1) P. cylindracea (Ward et Magath, 1918) mainly in Perca flavescens (Mitchill) (Percidae) but also in several other fish species, 2) $P$. kobuleji Molnár et Fernando, 1975 in Catostomidae, and 3) P. rubra (Leidy, 1856) in Moronidae (Molnár and Fernando 1975a,b, Moravec et al. 2006a,b, 2010b, Measures et al. 2017). However, none of these species possesses a gubernaculum the dorsal barb of which forms a conspicuous plate-like extension similar to that in P. haemulontis.
Only one philometrid male specimen was recovered from the ovary of $H$. aurolineatum. Although its body length is slightly longer than that of $P$. haemulontis males from $H$. plumierii (see above), the general morphology, including the shape of the anterior end of body, the length of spicules and the structure of the caudal end (Fig. 4), is practically identical with this species. Unfortunately, the gubernaculum of this specimen was withdrawn inside the body and, therefore, its distal portion could not be studied by SEM to confirm the conspecificity with $P$. haemulontis. Nevertheless, the fish hosts of both these forms belong to the same genus and occur in the same region, so that the nematode male from $H$. aurolineatum can be provisionally identified as $P$. haemulontis.

\section{Philometra synagridis Moravec, Bakenhaster et Fajer- \\ Ávila, 2014 \\ Fig. 6}

Male (4 specimens studied by LM; measurements of specimens in original description in parentheses): Body whitish, 3.84-4.49 (4.37-4.69) mm long, maximum width 48-51 (42-60); anterior part of body somewhat narrowed just posterior to cephalic end; body width at this narrowed part 21 (18-30). Maximum width/body length $1: 80-89$ (1 : 78-106); width of cephalic end 18-24 (21-27), that of posterior end 24-30 (30-36). Cephalic end rounded. Oesophagus 348-402 (513-603) long, forming 9-10\% (12-14\%) of body length; posterior part of muscular oesophagus overlapped by well-developed oesophageal gland 18-24 (18-24) wide with large cell nucleus in middle. Oesophageal nucleus and nerve ring 246-330 (276-399) and 180-195 (165-216), respectively, from anterior extremity. Excretory pore 195-233 (213-273) from anterior end. Posterior end of body blunt. Spicules equal or slightly subequal in length; length of larger spicule 180-195 (192-219), of smaller spicule 174-192 (186-213); length ratio of spicules 1 : 1.00-1.03; longer spicule representing 4-5\% (4-5\%) of body length. Gubernaculum narrow, 69-84 (87-90) long, with anterior portion somewhat dorsally bent; length of bent part 24-33 (10-11), representing 31-41\% (10-12\%) of entire gubernaculum length. Length ratio of gubernaculum and larger spicule $1: 2.22-2.74$ (1:2.21-2.43).

Gravid female (1 larvigerous specimen): Body of fixed specimen brownish; anterior part of body wider than posterior part. Body $152 \mathrm{~mm}$ long, maximum width 816; maximum width/body length $1: 186$. Cuticle smooth. Width of cephalic end 272. Cephalic papillae small. Oesophagus including anterior bulbous inflation $1.14 \mathrm{~mm}$ long, comprising $0.8 \%$ of body length; anterior inflation 163 long and 150 wide; maximum width of posterior part of oesophagus including gland 163. Oesophageal gland well developed, opening into oesophagus just posterior to nerve ring, with distinct cell nucleus in middle (Fig. 6B). Nerve ring and oesophageal nucleus 313 and 911, respectively, from anterior extremity. Small ventriculus present, 41 long and 136 wide. Length of intestinal ligament 993. Vulva and anus absent. Ovaries reflexed, situated near body ends (Fig. $6 \mathrm{~B})$. Uterus filled with numerous first-stage larvae and eggs (Fig. 6B, F). Body length of larvae from uterus $(n=$ 5) 459-495, maximum width 15-18; length of oesophagus 

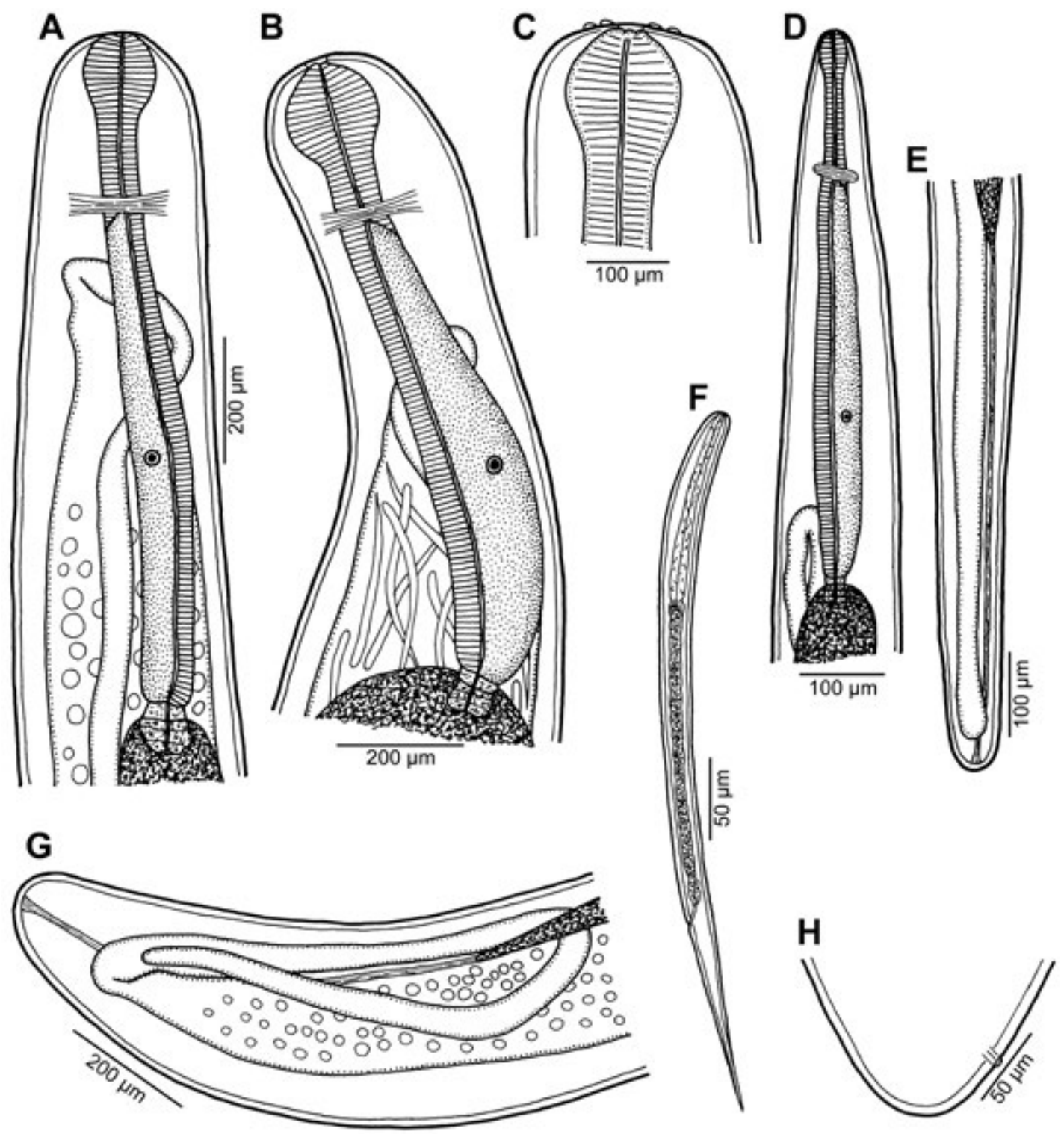

Fig. 6. Philometra synagridis Moravec, Bakenhaster et Fajer-Ávila, 2014 from the ovary of Lutjanus synagris (Linnaeus), females. A, B - anterior end of subgravid and gravid specimens, respectively, lateral views; $\mathbf{C}$ - cephalic end of gravid specimen, lateral view; $\mathbf{D}, \mathbf{E}$ - anterior and posterior ends of nongravid specimen, respectively, lateral views; $\mathbf{F}$ - larva from uterus, lateral view; $\mathbf{G}$ - posterior end of subgravid specimen, lateral view; $\mathbf{H}$ - caudal end of gravid specimen, lateral view.

$129-135$ (27-29\% of body length), of sharply pointed tail $132-144(27-31 \%)$. Posterior end of female body rounded, 177 wide, with pair of minute subterminal papilla-like caudal projections (Fig. $6 \mathrm{H}$ ).

Subgravid female (6 ovigerous specimens): Body of fixed specimens brownish. Body length $47-153 \mathrm{~mm}$, maximum width 340-639; maximum width/body length 1 : 118-186. Width of cephalic end 150-272. Oral aperture oval, surrounded by small cephalic papillae arranged in 2 circles; inner circle consisting of 4 submedian and 2 lateral single papillae, outer circle formed by 4 submedian pairs of papillae. Oesophagus including anterior bulbous inflation 1.05-1.26 long, comprising $1.1-2.2 \%$ of body length; anterior inflation 68-150 long and 68-144 wide; maximum width of posterior part of oesophagus including gland $82-$ 136 (Fig. 6A). Nerve ring and oesophageal nucleus 245313 and 653-843, respectively, from anterior extremity.
Ventriculus 27-54 long, 54-136 wide. Length of intestinal ligament 408-1,197. Vulva and anus absent. Uterus filled with many spherical eggs. Posterior end rounded, 82-190 wide, without caudal projections (Fig. 6G).

Nongravid female ( 2 specimens without eggs): Body length 7.90-10.66 mm, maximum width 177-190; maximum width/length ratio $1: 45-56$. Width of anterior end 41-54, of posterior end 54. Entire oesophagus 748-802 long and 41-51 wide. Anterior oesophageal bulb 60-66 long, 42 wide. Nerve ring and oesophageal nucleus $177-$ 204 and 530-612, respectively, from anterior extremity (Fig. 6D). Intestinal ligament 653-897 long. Vulva and anus absent. Uterus empty. Caudal end rounded (Fig. 6E).

Host: Lane snapper Lutjanus synagris (Linnaeus) (Lutjanidae, Perciformes), 156-198 mm SL.

Site of infection: Gonad (ovary and testes). 

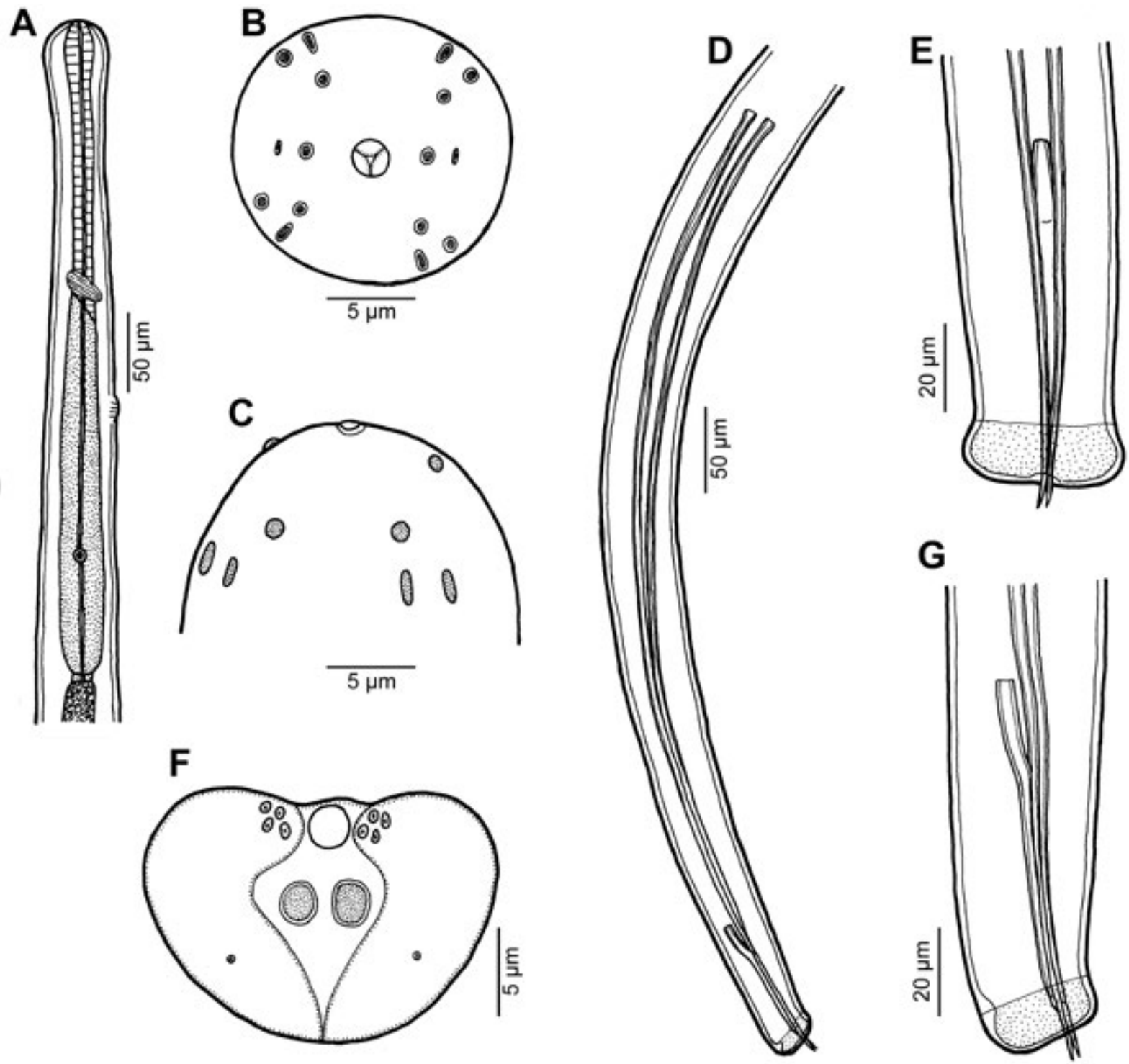

Fig. 7. Philometra margolisi Moravec, Vidal-Martínez et Aguirre-Macedo, 1995 from the ovary of Hyporthodus nigritus (Holbrook), male. A - anterior end of body, lateral view; B, C - cephalic end, apical and dorsoventral views, respectively; $\mathbf{D}$ - posterior end of body, lateral view; $\mathbf{E}, \mathbf{F}$ - caudal end, ventral and apical views, respectively; $\mathbf{G}$ - caudal end, lateral view.

Locality: Gulf of Mexico, West Florida Shelf, between approximately 10 and $70 \mathrm{~km}$ westward of Charlotte Harbor, Florida, $26.72535,-82.99491 ; 26.75033,-82.59633$; and 26.83318, -82.41052; USA (collected 16 April 2017 and 17 July 2018).

Prevalence and intensity: $8 \%$ determined by gross evaluation (5 infected/60 examined, male and female hosts). Intensity exceeded 7 female nematodes in one specimen, but fragmentation of worms prevented reliable counts beyond that. Three host specimens with complete counts had 1, 3 and 6 female worms, respectively. Intensity of male worms was $1-9$ (5.4, $\mathrm{n}=5$ ).

Deposition of voucher specimens: SNMNH USNM 1616443 ; IPCAS N-1037.

Other material: Two additional female specimens were collected on 16 April 2017, one from each of two host specimens that also yielded voucher specimens listed above, but these were used for DNA extraction (data not presented) and are no longer available for examination.
Remarks. This species was established by Moravec et al. (2014) solely from male specimens collected from $L$. synagris in the Gulf of Mexico. Males of the present material, studied only by LM, were morphologically identical with those reported in the original description; slight biometrical differences recorded can be considered to be within an intraspecific variability of this species.

Nongravid (without eggs), subgravid (ovigerous) and gravid (larvigerous) females of $P$. synagridis are described in the present paper for the first time. The present study shows that the general female morphology of $P$. synagridis is rather similar to other congeneric gonad-infecting species. Therefore, the eight species of Philometra parasitic in the gonads of Lutjanus spp. with known males, i.e., $P$. argentimaculati Moravec et Manoharan, 2014; P. brevicollis Moravec et Justine, 2011; P. carponotati Moravec et Diggles, 2014; P. fulvi Moravec et Manoharan, 2014; P. latispicula Moravec, Bakenhaster et Fajer-Ávila, 2014; $P$. longispicula Moravec, Bakenhaster et Fajer-Ávila, 
2014; P. mira Moravec et Justine, 2011; and P. synagrid$i s$, are mainly distinguishable based on male morphology (Moravec and Justine 2011, Moravec and Diggles 2014a, Moravec and Manoharan 2014b, Moravec et al. 2014).

Moravec et al. (2014) considered all gonad-infecting congeneric nematodes from L. synagris, previously reported by Linton (1907), Rees (1970), Martínez and Ventosa (1982) and Cavalcanti et al. (2010) as Ichthyonema sp., Philometra sp. or P. lateolabracis from Bermuda or from off Cuba and Brazil, to be probably representatives of P. synagridis. All these records were solely based on observations of females. According to Martínez and Ventosa (1982), the body length of gravid, larvigerous females (misidentified as $P$. lateolabracis) was $109-152 \mathrm{~mm}$, which corresponds to that $(152 \mathrm{~mm})$ of the only gravid female of $P$. synagridis in the present material. Since also the morphology of both these forms are much the same, there is no doubt that they belong to one and the same species.

Cavalcanti et al. (2010) insufficiently described female specimens of Philometra sp. from the ovary of L. synagris from off the Atlantic coast of Brazil. The body lengths of their allegedly gravid females were $30-70 \mathrm{~mm}$, in contrast to $152 \mathrm{~mm}$ of the presently reported gravid, larvigerous female of $P$. synagridis. This indicates that these authors had only ovigerous (= subgravid) specimens at their disposal. Considering the high degree of host specificity in gonad-infecting species of Philometra, the host species and the region of occurrence, it is apparent that the above-mentioned Brazilian nematodes were conspecific with $P$. synagridis. Consequently, the distribution of $P$. synagridis seems to coincide with the distribution area of its host species, i.e., the western Atlantic Ocean (Froese and Pauly 2020).

\section{Philometra margolisi Moravec, Vidal-Martínez et}

Aguirre-Macedo, 1995

Figs. 7, 8

Male (2 specimens): Body whitish, filiform, tapering to both ends, 2.35-2.65 mm long, maximum width at middle 54-60; anterior part of body somewhat narrower just posterior to cephalic end (Figs. 7A, 8A); body width at this narrowed part 27. Maximum width/body length ratio $1: 44$; width of cephalic end 30-33, that of posterior end 27. Cuticle smooth. Cephalic end rounded. Oral aperture small, circular, with 3 distinct oesophageal lobes (Figs. 7B, 8B). Cephalic papillae 14 in number, arranged in 2 circles: outer circle formed by 4 submedian pairs of papillae; inner circle formed by 4 submedian and 2 lateral papillae (Figs. 7B,C, 8B,C). Small lateral amphids just posterior to lateral papillae of internal circle (Figs. 7B, 8B). Oesophagus $429-510$ long (18-19\% of body length), maximum width 24 , slightly inflated at anterior end; posterior part of muscular oesophagus overlapped by well-developed oesophageal gland with large cell nucleus (Fig. 7A); anterior oesophageal inflation 31-33 long and 15-18 wide. Nerve ring, excretory pore and oesophageal nucleus 150-156, 216-240 and 331-333, respectively, from anterior extremity. Posterior end of body blunt, with broad, V-shaped mound extending laterally (Figs. 7F, 8D-F). Four pairs of very flat, indistinct caudal papillae close to each other situated on sides of cloacal aperture on mound and pair of larger papillae located posteriorly to cloaca outside mound (Figs. 7F, 8D,E). Pair of small phasmids present at posterior part of each mound arm (Figs. 7F, 8D,E). Spicules slender, very long, approximately equal, with slightly expanded proximal and sharply pointed distal ends (Fig. 7D); length of spicules $504-579$ or $21-22 \%$ of body length. Gubernaculum 87-93 long, with anterior portion somewhat dorsally bent; length of anterior bent part 12-24, representing $13-28 \%$ of entire gubernaculum length (Fig. 7D,E,G). Length ratio of gubernaculum and spicules $1: 5.42-6.66$. Spicules and gubernaculum well sclerotised, yellowish, anterior part of gubernaculum colourless.

Host: Warsaw grouper Hyporthodus nigritus (Holbrook) (Serranidae, Perciformes); $976 \mathrm{~mm}$ SL.

Site of infection: Ovary.

Localities: Straits of Florida, Warsaw Hole off Marquesas Keys, Florida, 24.36063; -82.32511, USA (collected 28 June 2018). West Florida Shelf, Sticky Grounds reef system approximately $170 \mathrm{~km}$ off Tampa Bay, Florida, $27.7^{\circ} ;-84.5^{\circ}$ (collected 1 March 2019).

Prevalence and intensity: 2 fish infected/2 fish examined; 1 nematode specimen per fish.

Deposition of voucher specimen: IPCAS N-622.

Remarks. The morphology and measurements of the two available male specimens are very similar to those of $P$. margolisi, a gonad-infecting species described from Epinephelus morio (Valenciennes) (Serranidae) in the Gulf of Mexico (Moravec et al. 1995, 2017a). Even though their spicules are somewhat longer (504-579 $\mu \mathrm{m}$ vs 420-498 $\mu \mathrm{m})$ and the distal portion of their gubernaculum could not be studied by SEM, we consider these nematodes to be representatives of this species. A somewhat different length of spicules may be within the intraspecific variability of P. margolisi.

The single male of $P$. margolisi was found in the ovary of the same fish host specimen (H. nigritus) as that of Philometra andersoni sp. $\mathrm{n}$.

\section{Philometra andersoni sp. n.}

Figs. 9, 10

ZooBank number for species:

urn:1sid:zoobank.org:act:3079639E-6158-4A6A-8846-FCB1BCE08DF7

Male (1 specimen, holotype): Body whitish, filiform, tapering to both ends, $4.16 \mathrm{~mm}$ long, maximum width at middle 60; anterior part of body not narrowed just posterior to cephalic end (Figs. 9A, 10C). Maximum width/ body length ratio $1: 69$; width of cephalic end 27, that of posterior end 33. Cuticle smooth. Cephalic end rounded. Oral aperture small, circular, with 3 distinct anterior oesophageal lobes. Cephalic papillae 14 in number, arranged in 2 circles: external circle formed by 4 submedian pairs of papillae; internal circle formed by 4 submedian and 2 lateral papillae (Figs. 9B, 10A,B). Small lateral amphids just posterior to lateral papillae of internal circle (Figs. 9B, 10A,B). Oesophagus 576 long (14\% of body length), maximum width 24 , slightly inflated at anterior end; posterior part of muscular oesophagus overlapped by well-develo- 


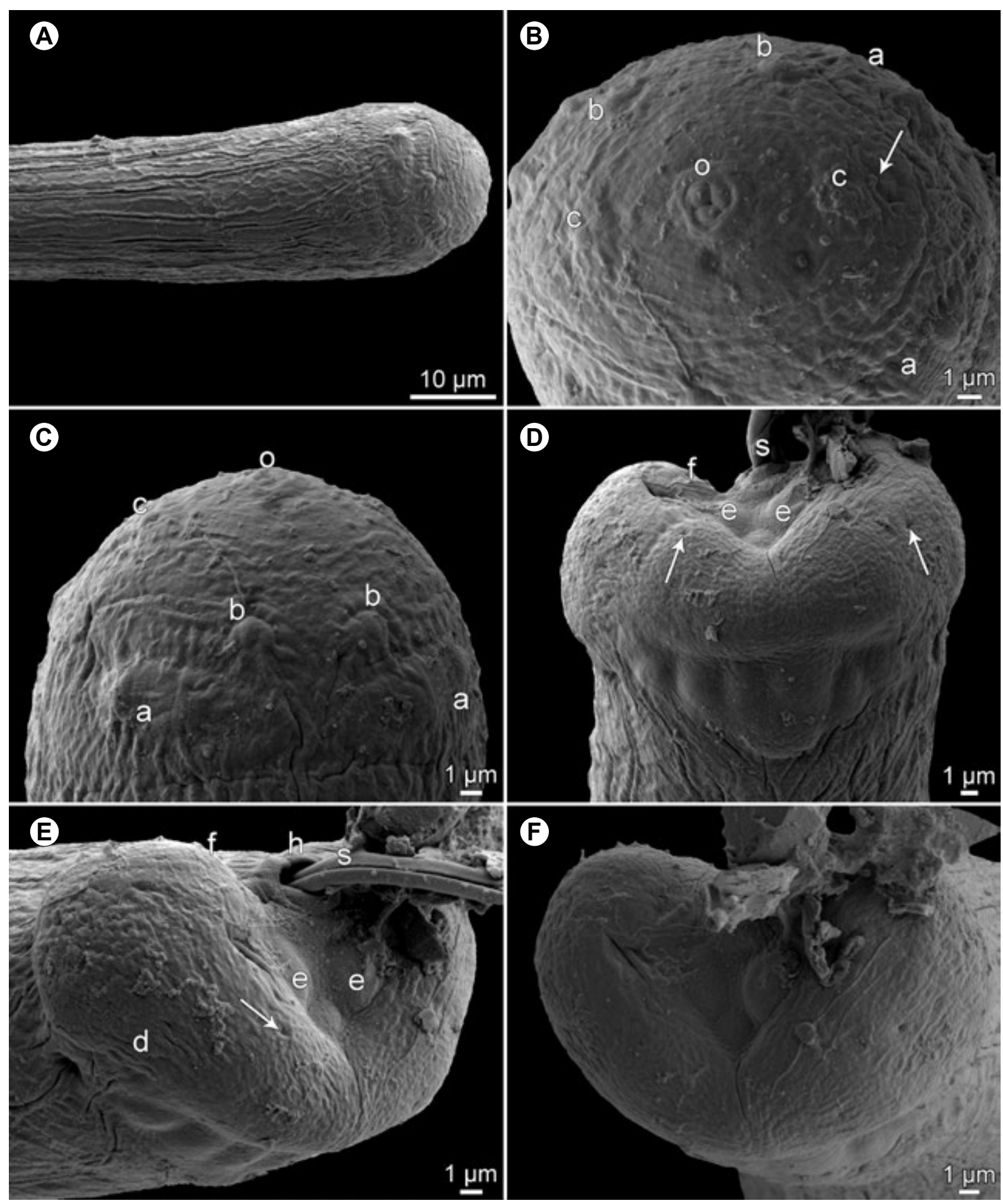

Fig. 8. Philometra margolisi Moravec, Vidal-Martínez et Aguirre-Macedo, 1995 from the ovary of Hyporthodus nigritus (Holbrook), scanning electron micrographs of male. $\mathbf{A}$ - anterior end of body; $\mathbf{B}, \mathbf{C}$ - cephalic end, apical and dorsoventral views, respectively (arrow indicates amphid); D, E - caudal end, subdorsal and sublateral views, respectively (arrows indicate phasmids); $\mathbf{F}$ - caudal end, apical view. Abbreviations: a - submedian pair of cephalic papillae of outer circle; $\mathrm{b}$ - submedian cephalic papilla of inner circle; $\mathrm{c}$ - lateral cephalic papilla of inner circle; $d$ - caudal mound; $\mathrm{e}$ - large postanal caudal papilla; $\mathrm{f}$ - group of four small adanal papillae; $\mathrm{h}$ - cloacal aperture; $\mathrm{o}$ - oral aperture; $\mathrm{s}$ - spicule. 

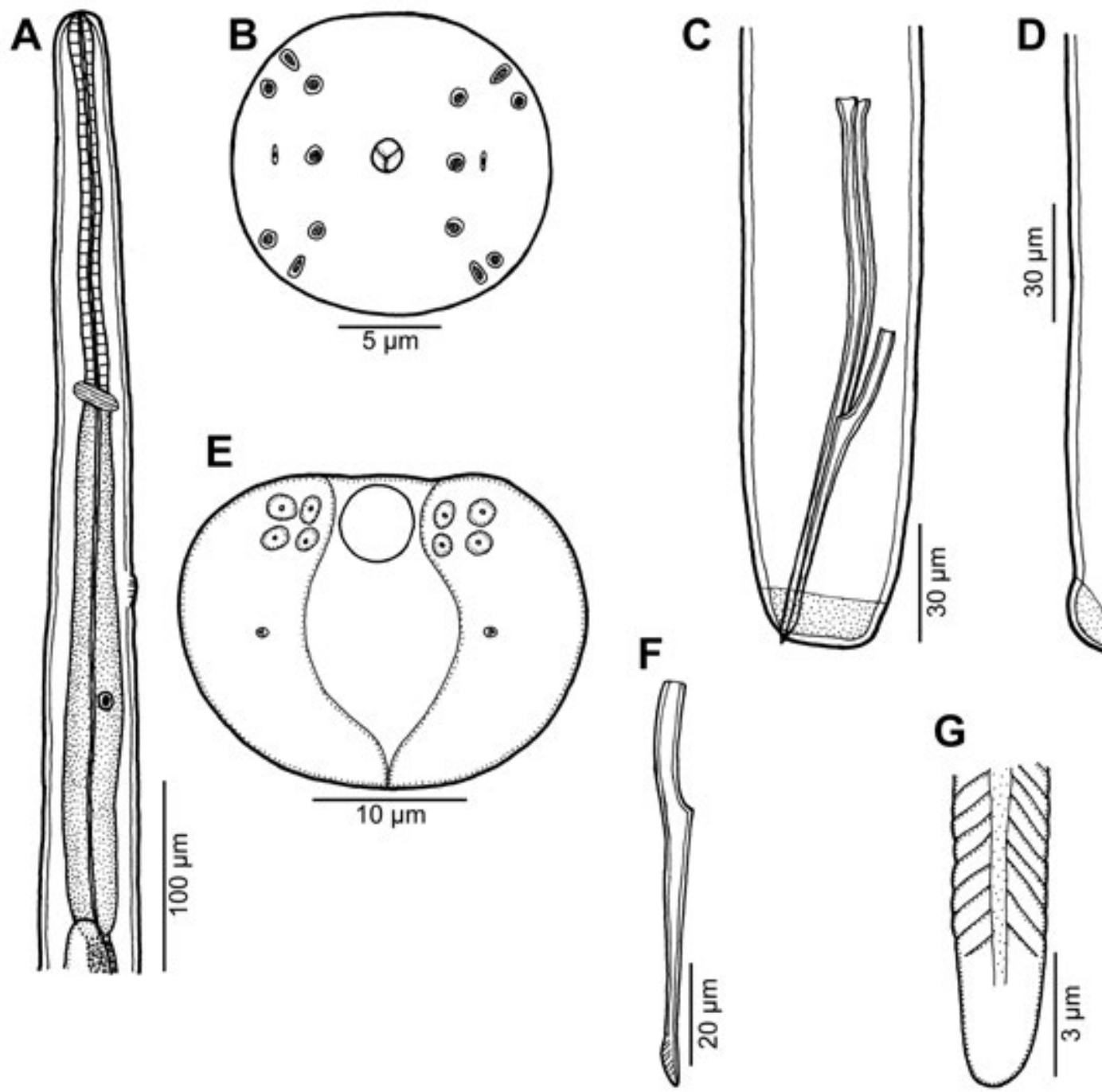

Fig. 9. Philometra andersoni sp. n. from the ovary of Hyporthodus nigritus (Holbrook), male. A - anterior end of body, lateral view; $\mathbf{B}$ - cephalic end, apical view; C, D - posterior end, lateral and ventral views, respectively; $\mathbf{E}$ - caudal end, apical view; $\mathbf{F}$ - gubernaculum, lateral view; $\mathbf{G}$ - distal tip of gubernaculum, dorsal view.

ped oesophageal gland with large cell nucleus (Fig. 9A); anterior oesophageal inflation 33 long and 18 wide. Nerve ring, excretory pore and oesophageal nucleus 189, 267 and 378, respectively, from anterior extremity.

Posterior end of body blunt, somewhat laterally expanded; caudal mound indistinct, appearing as V-shaped (Figs. 9E, 10E,F). Four pairs of very flat, hardly visible caudal papillae close to each other situated on sides of cloacal aperture on mound; pair of small phasmids present at about middle of each mound arm (Figs. 9E, 10E,F). Spicules slender, approximately equal in length, with slightly expanded proximal and sharply pointed distal ends (Fig. 9C,D); length of spicules 162 or 4\% of body length. Gubernaculum 102 long, with anterior portion somewhat dorsally bent; length of anterior bent part 30, representing $29 \%$ of entire gubernaculum length; distal end of gubernaculum rounded, dorsal surface with 2 lateral rows of numerous, oblique lamella-like structures separated from each other by narrow, somewhat depressed median smooth field; lamella-like structures ending posteriorly at short distance to smooth apex of gubernaculum (Figs. 9C,D,F,G, 10D). Len- gth ratio of gubernaculum and spicules $1: 1.59$. Spicules and gubernaculum well sclerotised; spicules and gubernaculum yellowish, anterior part of gubernaculum colourless.

Nongravid female (1 mature specimen): Body length $3.25 \mathrm{~mm}$, maximum width 51; maximum width/length ratio $1: 64$. Width of anterior end 30, of posterior end 27 . Entire oesophagus 405 long and 27 wide. Nerve ring and oesophageal nucleus 204 and 261, respectively, from anterior extremity. Vulva and incompletely developed vagina present, former situated $2.16 \mathrm{~mm}$ from anterior extremity (at $67 \%$ of body length). Uterus empty. Caudal end rounded.

Type host: Warsaw grouper Hyporthodus nigritus (Holbrook) (Serranidae, Perciformes); 976 mm SL.

Site of infection: Ovary.

Type locality: Straits of Florida, Warsaw Hole off Marquesas Keys, Florida, 24.36063, -82.32511, USA (collected 28 June 2018).

Prevalence and intensity: 1 fish infected/1 fish examined; 2 nematode specimens. 

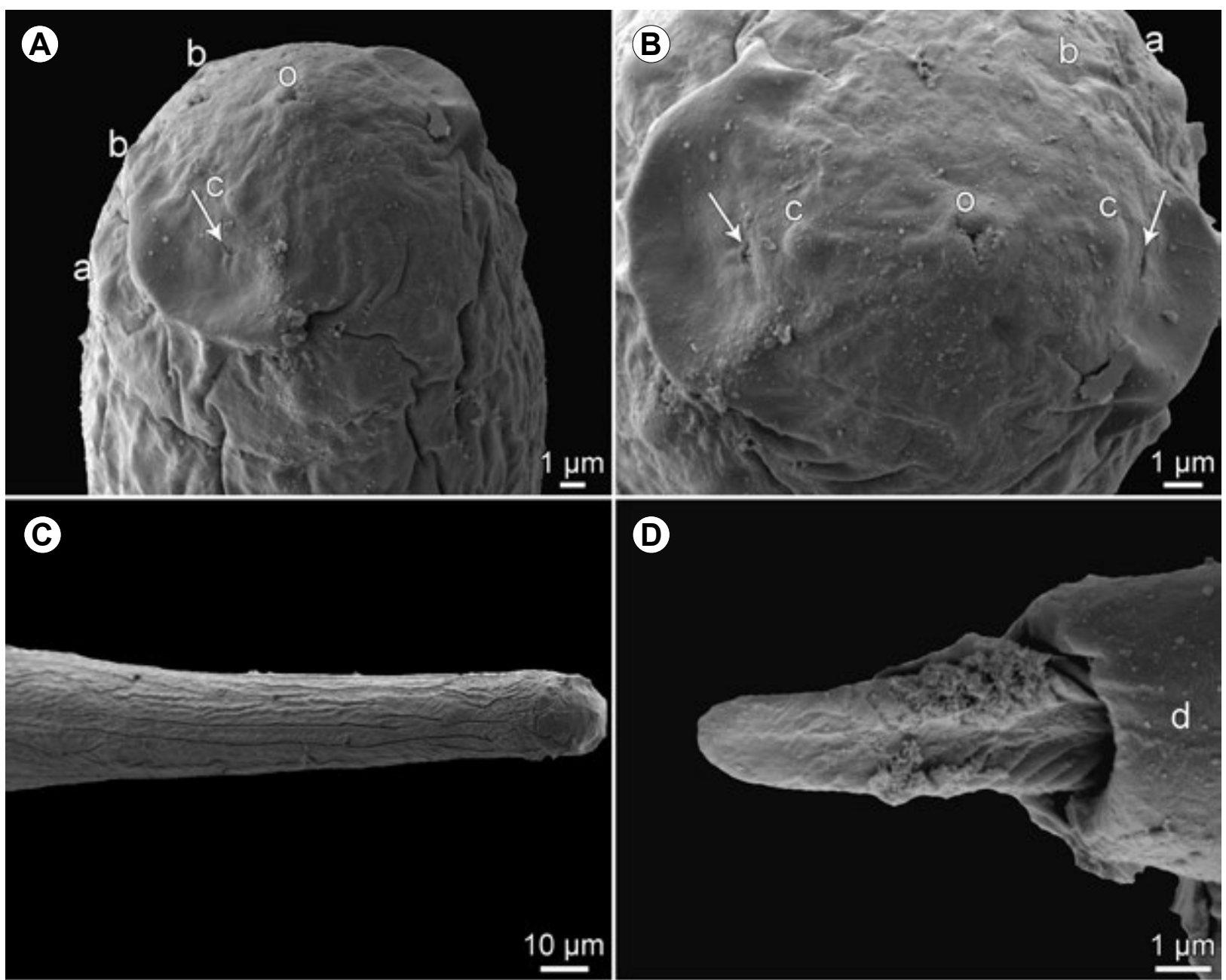

\section{D}
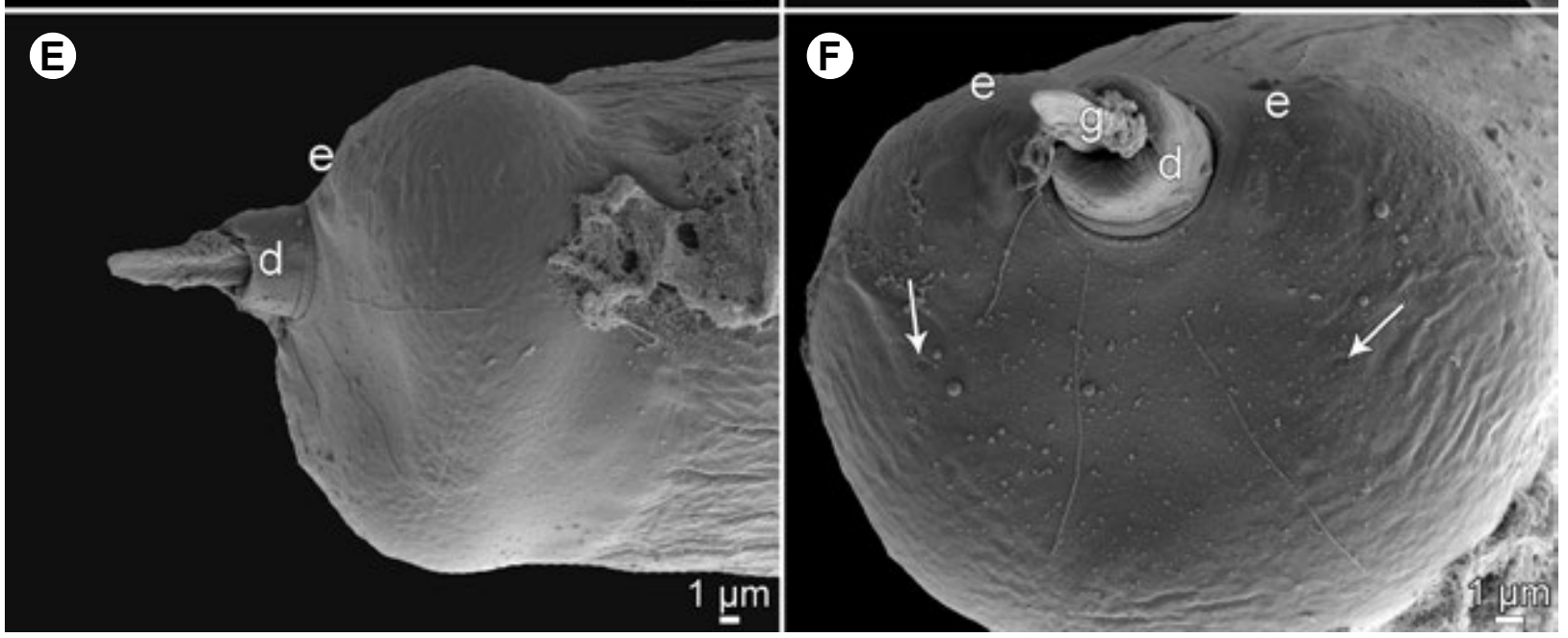

Fig. 10. Philometra andersoni sp. n. from the ovary of Hyporthodus nigritus (Holbrook), scanning electron micrographs of male. A, B - cephalic end, subapical and apical views, respectively (arrows indicate amphids); C - anterior end of body; D - distal tip of gubernaculum, dorsal view; E, F - caudal end, subdorsal and apical views, respectively (arrows indicate phasmids). Abbreviations: a submedian pair of cephalic papillae of outer circle; $b$ - submedian cephalic papilla of inner circle; $c$ - lateral cephalic papilla of inner circle; $\mathrm{d}$ - everted wall of cloaca; $\mathrm{e}$ - group of four adanal papillae; $\mathrm{g}$ - gubernaculum; $\mathrm{o}$ - oral aperture.

Deposition of type specimen: IPCAS N-1210 (holotype mounted on SEM stub). Voucher specimen (1 small mature female in vial) deposited at the same place under the same catalogue number.

Etymology: This nematode species is named for the late, eminent Canadian nematodologist Roy C. Anderson, professor of zoology at the University of Guelph, Ontario, who contributed greatly to the knowledge of nematode parasites of vertebrates, including those parasitising fishes.

Remarks. To date, the following 17 species of Philometra are known to parasitise the gonads of hosts belonging 


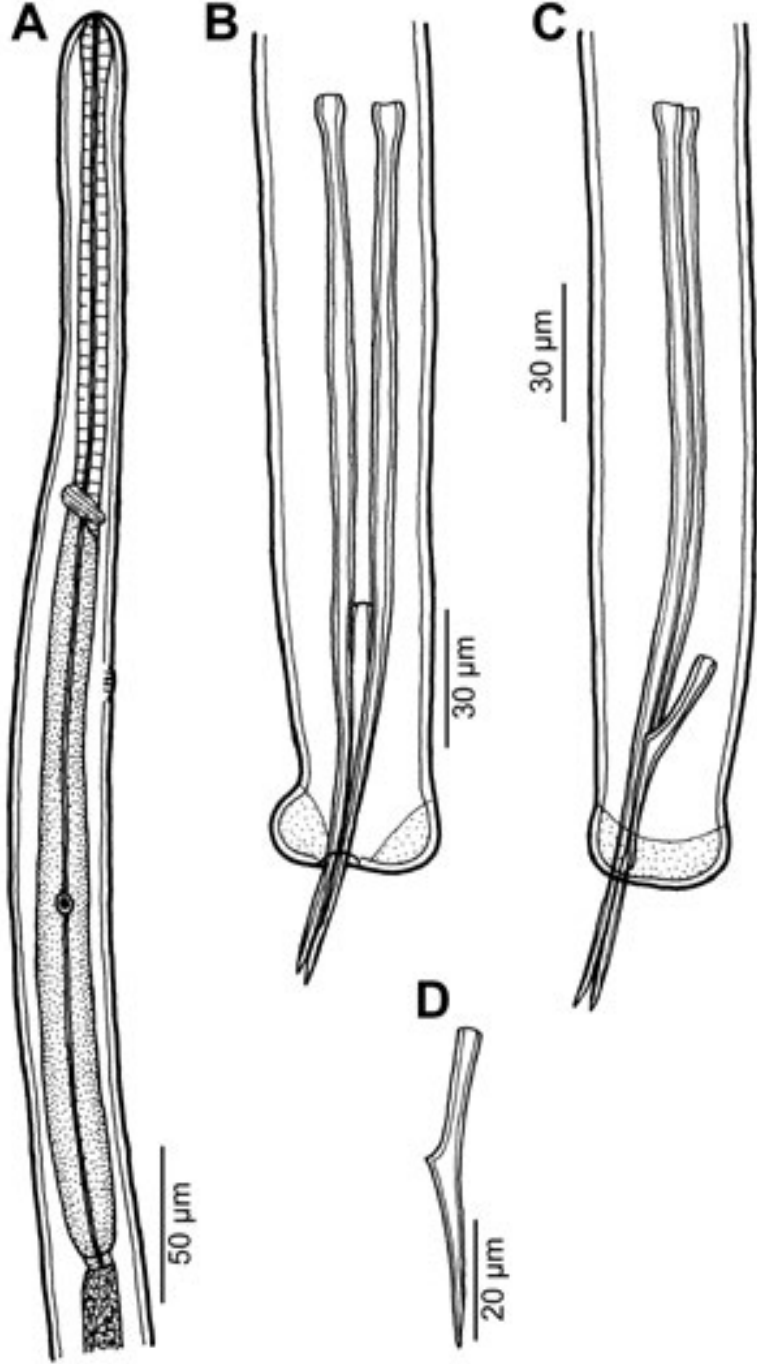

Fig. 11. Philometra sp. 1 from Rhomboplites aurorubens, male. $\mathbf{A}$ - anterior end of body, lateral view; $\mathbf{B}, \mathbf{C}$ - posterior end of body, ventral and lateral views, respectively; D - gubernaculum, lateral view.

to the fish family Serranidae: $P$. aenei Moravec, Chaabane, Neifar, Gey et Justine, 2016; P. cephalopholidis Moravec et Justine, 2015; P. charlestonensis Moravec, de Buron, Baker et González-Solís, 2008; P. cyanopodi Moravec et Justine, 2008; P. fasciati Moravec et Justine, 2008; P. hyporthodi Moravec et Bakenhaster, 2013; P. incognita Moravec et Bakenhaster, 2016; P. indica Moravec et Manoharan, 2014; P. inexpectata Moravec, Chaabane, Justine et Neifar, 2016; P. jordanoi (López-Neyra, 1951); P. margolisi; P. mexicana Moravec et Salgado-Maldonado, 2007; P. piscaria Moravec et Justine, 2014; P. rara Moravec, Chaabane, Neifar, Gey et Justine, 2017; P. serranellicabrillae Janiszewska, 1949; P. tropica Moravec et Manoharan, 2014; and P. tunisiensis Moravec, Chaabane, Neifar, Gey et Justine, 2016 (see Moravec et al. 2017b). Five of them ( $P$. charlestonensis, $P$. hyporthodi, $P$. incognita, $P$. margolisi and $P$. mexicana) occur in the region of the North-West Atlantic Ocean, including the Gulf of Mexico.
Of the above-mentioned species, by the length of spicules $(162 \mu \mathrm{m}) P$. andersoni resembles only $P$. inexpectata $(147-165 \mu \mathrm{m})$, a parasite of Mycteroperca rubra (Bloch) in the Mediterranean Sea (Moravec et al. 2016c), P. fasciati (147-156 $\mu \mathrm{m})$, a parasite of Epinephelus fasciatus (Forsskål) in the South Pacific Ocean (off New Caledonia) (Moravec and Justine 2005, 2008), and P. tropica (168-186 $\mu \mathrm{m})$ parasitising Epinephelus bleekeri (Vailland) in the Indian Ocean (off India) (Moravec and Manoharan 2014a). The spicules of other species are distinctly shorter or longer, which also concerns only recently described males of $P$. serranellicabrillae, a parasite of Serranus cabrilla (Linnaeus) in the region of the Mediterranian Sea (Janiszewska 1949, Moravec et al. 2006b), with spicules 90-115 $\mu \mathrm{m}$ long (Ghanmi et al. 2019).

However, in contrast to the new species, the males of $P$. inexpectata are much shorter (1.97-2.43 $\mu \mathrm{m}$ vs 4.16 $\mu \mathrm{m})$ and they possess two large caudal papillae behind the cloacal apertute ( $v s$ such papillae absent). The males of $P$. fasciati have not yet been examined by SEM, but this species can be differentiated by the smaller body length of the male (2.75-3.32 $\mathrm{mm}$ vs $4.16 \mathrm{~mm})$ and a shorter gubernaculum (69-84 $\mu \mathrm{m}$ vs $102 \mu \mathrm{m})$. The ventral margin of spicules of $P$. tropica is conspicuously flared between the second and the fourth quarter of its length ( $v s$ spicules without such an extension) and the gubernaculum is longer (120-138 $\mu \mathrm{m} v s 102 \mu \mathrm{m})$.

Two gonad-infecting species of Philometra were previously described from fishes of the genus Hyporthodus: P. hyporthodi from H. flavolimbatus (Poey) in the Gulf of Mexico (Moravec and Bakenhaster 2013) and P. rara from $H$. haifensis (Ben-Tuvia) in the Mediterranean Sea (Moravec et al. 2017b). In contrast to P. andersoni, P. hyporthodi has shorter spicules $(135-138 \mu \mathrm{m} v s 162 \mu \mathrm{m})$ and gubernaculum $(84 \mu \mathrm{m} v s 102 \mu \mathrm{m})$, whereas $P$. rara possesses longer spicules $(216-219 \mu \mathrm{m})$; moreover, both these species have a pair of large postcloacal papillae, which are absent in the new species, and their two or more posterior-most dorsal transverse lamellar structures on the distal end of the gubernaculum are continuous, not medially interrupted.

A single male of $P$. andersoni and one small mature female tentatively assigned to this species were collected from the ovary of the same fish host specimen $(H$. nigritus) as the male of $P$. margolisi (see above). Whereas the male of $P$. andersoni is easily distinguished from that of $P$. margolisi by the length of spicules (162 $\mu \mathrm{m} v s$ 420-498 $\mu \mathrm{m})$, in the case of the available small female it is not quite clear whether it belongs to the former or to the latter species. Considering that the demonstrated definitive host of P. margolisi is Epinephelus morio, in which conspecific gravid females of this nematode also occur, it is highly probable that $H$. nigritus serves as only a paradefinitive host (one in which the parasite attains maturity but is unable to reproduce; see Odening 1976) for this species, but as the definitive host for $P$. andersoni. Nevertheless, further studies of gonad-infecting Philometra spp. in H. nigritus are needed to confirm this. A similar case when the males of two different species of Philometra co-infecting the ovary of the same host species was recorded by Moravec and 


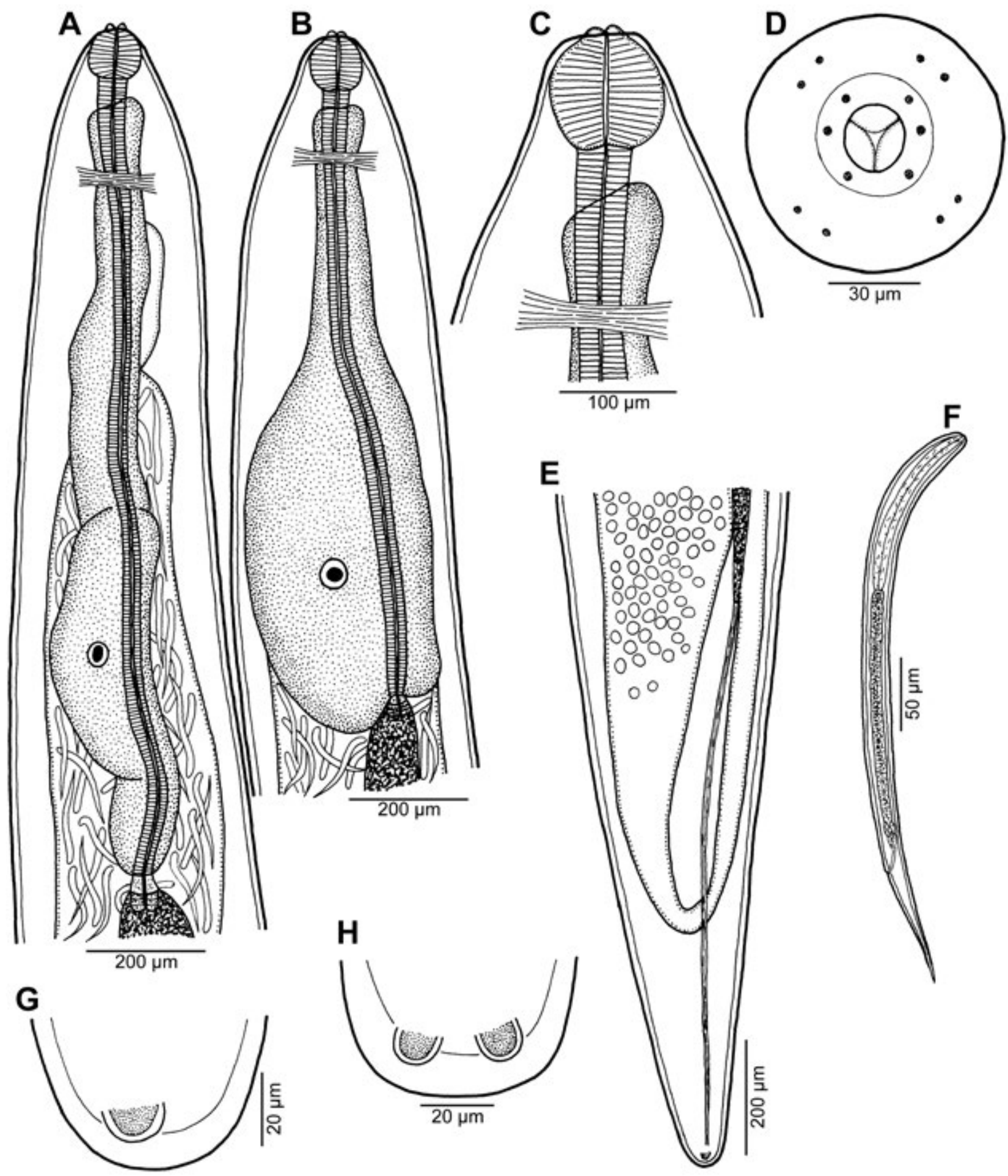

Fig. 12. Philometra sp. 2 from the subcutaneous tissue of the anterior-most head sinuses Hyporthodus niveatus (Valenciennes), gravid female. A, B - anterior ends of two different specimens, lateral views; C, D - cephalic end, lateral and apical views, respectively; $\mathbf{E}-$ posterior end, lateral view; $\mathbf{F}$ - larva from uterus, lateral view; $\mathbf{G}, \mathbf{H}$ - caudal end, lateral and ventral views, respectively.

Justine (2011), who had found the males of $P$. brevicollis and P. mira in Lutjanus vitta (Quoy et Gaimard) (Lutjanidae) off New Caledonia.

\section{Philometra sp. 1}

Fig. 11

Male (1 specimen): Body whitish, filiform, tapering to both ends, $3.78 \mathrm{~mm}$ long, maximum width at middle 51 ; anterior part of body not narrowed just posterior to ce- phalic end (Fig. 11A). Maximum width/body length ratio 1 : 74; width of cephalic end 21, that of posterior end 33 . Cuticle smooth. Cephalic end rounded. Oesophagus 381 long ( $10 \%$ of body length), maximum width 15 , slightly inflated at anterior end; posterior part of muscular oesophagus overlapped by well-developed oesophageal gland with large cell nucleus in middle (Fig. 11A). Nerve ring, excretory pore and oesophageal nucleus 153,183 and 270 , 
respectively, from anterior extremity. Structure of caudal end could not be studied by SEM. Posterior end of body blunt, somewhat expanded laterally (Fig. 11B,C); details of its structure could not be studied by SEM. Spicules slender, approximately equal in length, with slightly expanded proximal and sharply pointed distal ends (Fig. 11B,C); length of spicules 207 or 5\% of body length. Gubernaculum 78 long, with anterior portion somewhat dorsally bent; length of anterior bent part 30, representing $38 \%$ of entire gubernaculum length; distal part of gubernaculum appearing as slender, pointed, without dorsal barb in lateral view under LM (Fig. 11C,D). Length ratio of gubernaculum and spicules $1: 2.65$. Spicules and gubernaculum well sclerotised, yellowish, anterior part of gubernaculum colourless.

Host: Vermilion snapper Rhomboplites aurorubens (Cuvier) (Lutjanidae, Perciformes); $178 \mathrm{~mm}$ SL.

Site of infection: Ovary.

Locality: Gulf of Mexico, West Florida Shelf approximately 80 $\mathrm{km}$ due west of southern Manasota Keys, Florida, 26.90468, -83.15333, USA (collected 18 July2018).

Prevalence and intensity: 5\% (1 fish infected/21 fish examined; all examinations conducted on gonad rinsings under a dissecting microscope), 1 nematode specimen.

Deposition of specimen: Not deposited (destroyed during the SEM procedure).

Remarks. Eight nominal gonad-infecting species of Philometra have so far been described from fishes belonging to the Lutjanidae (all from Lutjanus spp.): P. argentimaculati: P. brevicollis; P. carponotati; P. fulvi; P. latispicula; P. longispicula; P. mira; and P. synagridis Moravec, Bakenhaster et Fajer-Ávila, 2014 (see Moravec and Justine 2011, Moravec and Diggles 2014a, Moravec and Manoharan 2014b, Moravec et al. 2014). In addition, Al-Jahdali (2014) reported P. madai Quiazon, Yoshinaga et Ogawa, 2008, a parasite of sparid fishes, from the ovary of Lutjanus monostigma (Cuvier) in the Red Sea, but this species identification based solely on available female specimens was evidently wrong.

Of the above-mentioned species, by the length of spicules $(207 \mu \mathrm{m})$ Philometra sp. 1 resembles only $P$. argentimaculati $(219-228 \mu \mathrm{m})$ from Lutjanus argentimaculatus (Forsskål) in the Bay of Bengal, P. carponotati (225-252 $\mu \mathrm{m}$ ) from L. carponotatus (Richardson) off the northern coast of Australia and P. synagridis (186-219 $\mu \mathrm{m}$ ) from L. synagris (Linnaeus) in the Gulf of Mexico; in the remaining species the spicules are shorter than $150 \mu \mathrm{m}$ (P. fulvi, P. latispicula and P. mira) or longer than $270 \mu \mathrm{m}$ ( $P$. brevicollis and $P$. longispicula).

While we cannot fully demonstrate that Philometra sp. 1 belongs to an undescribed species, taking into account the high degree of host specificity of gonad-infecting species of Philometra and the fact that the host of Philometra sp. 1 belongs to a different genus from that of all other lutjanid hosts of Philometra spp. (Rhomboplites Gill vs Lutjanus Bloch), this is highly probable. Still, since 2005, one of us (MB) has gathered negative data from macroscopic parasitological evaluations of $>200$ specimens of $R$. $a u$ rorubens collected primarily from approximately the same locality as was the present infected specimen (i.e., off the Florida Gulf of Mexico coastline from Tampa Bay south to Naples, though somewhat nearer to shore generally $<60$ $\mathrm{km}$ ). As reported above for P. margolisi, philometrids, at least males, may occasionally infect paradefinitive hosts, so only additional collections can confirm that $R$. aurorubens serves as definitive host to a gonad-infecting species of Philometra. Since the only available specimen could not be studied by SEM, we refrain from establishing it as a new species.

\section{Philometra sp. 2}

Figs. 12, 13

Gravid female (4 larvigerous specimens): Body of fixed specimens brownish, somewhat tapering at both ends (Fig. 12A-C,E). Body 27.4-55.4 mm long, its maximum width at middle 585-707; maximum width/body length ratio 1 : 39-95. Cuticle finely transversely striated. Cephalic end rounded, 109-136 wide, with 3 distinctly protruding oesophageal teeth (lobes) 9-12 long (Figs. 12A-D, 13A,B). Oral aperture large, oval, surrounded by 14 small cephalic papillae arranged in 2 circles; inner circle of papillae consisting of 4 submedian and 2 lateral single papillae, whereas external circle formed by 4 submedian pairs of papillae; amphids not visible (Figs. 12D, 13A,B).

Oesophagus including anterior bulbous inflation 1.07$1.63 \mathrm{~mm}$ long, representing 2-6\% of body length; bulb 90-117 long and 96-111 wide; muscular oesophagus posterior to bulb and not covered by oesophageal gland 42-51 long and 45-75 wide. Oesophageal gland marked, extending anteriorly from posterior end of oesophagus to short distance posterior to bulb, thus exceeding considerably nerve ring anteriorly; large oesophageal gland nucleus 748-1,251 from anterior extremity. Posterior half of oesophageal gland conspicuously expanded, sometimes somewhat lobular (Fig. 12A,B); total length of oesophageal gland 925-1,510, its maximum width 177-394; anterior portion of oesophageal gland exceeding nerve ring anteriorly 82-218 long and 93-111 wide. Nerve ring 245-299 from anterior end of body. Small ventriculus 51-54 long and 42-54 wide present. Oesophagus opening into intestine through valve. Intestine light brown in colour, narrow, ending blindly; its posterior end attached to body wall near caudal end by narrow ligament 503-2.992 long (Fig. 12E).

Vulva and anus absent. Ovaries long, narrow, reflexed, situated near body ends (Fig. 12A,E). Uterus occupying most space of body, filled with numerous larvae and eggs; anteriorly uterus not reaching level of nerve ring. Larvae $(\mathrm{n}=5$ ) from uterus 369-435 long, maximum width 18 , length of oesophagus 120-141 (31-33\% of body length), of sharply pointed tail 63-87 (17-20\%) (Fig. 12F). Posterior end of female with 2 large, lateral rounded caudal projections (Fig. 12E,G,H).

Host: Snowy grouper Hyporthodus niveatus (Valenciennes) (Serranidae, Perciformes).

Site of infection: Subcutaneous tissue of anterior-most head sinuses near the juncture of left and right premaxillary ascending processes when jaw is contracted.

Locality: Gulf of Mexico, outer West Florida Shelf about 170 $\mathrm{km}$ due west of Treasure Island, Florida, and $30 \mathrm{~km}$ westward 
Table 1. Comparison of some measurements of gravid females of Philometra morii, Philometra sp. of Moravec et al. (2010) and present nematodes (Philometra sp. 2) from H. niveatus.

\begin{tabular}{|c|c|c|c|}
\hline & P. morii & Philometra sp. & $\begin{array}{l}\text { present specimens } \\
\text { (Philometra } \text { sp. } 2)\end{array}$ \\
\hline Length of body & $19-30 \mathrm{~mm}$ & $26-52 \mathrm{~mm}$ & $27-55 \mathrm{~mm}$ \\
\hline Maximum width / body length & $1: 33-34$ & $1: 35-76$ & $1: 39-95$ \\
\hline Length of oesophagus & $1.09-1.50 \mathrm{~mm}$ & $1.01-1.41 \mathrm{~mm}$ & $1.07-1.63 \mathrm{~mm}$ \\
\hline ( $\%$ of body length) & $4-6 \%$ & $2-4 \%$ & $2-6 \%$ \\
\hline Oesophageal teeth & + & $+/-$ & + \\
\hline Length of larvae & $513-522 \mu \mathrm{m}$ & $375-426 \mu \mathrm{m}$ & $369-435 \mu \mathrm{m}$ \\
\hline Host & Epinephelus morio & Mycteroperca microlepis & Hyporthodes niveatus \\
\hline Location & $\begin{array}{l}\text { Subcutaneous tissue of buccal } \\
\text { cavity and sinuses }\end{array}$ & $\begin{array}{l}\text { Subcutaneous tissue of buccal } \\
\text { cavity and sinuses }\end{array}$ & Subcutaneous tissue; sinuses \\
\hline
\end{tabular}
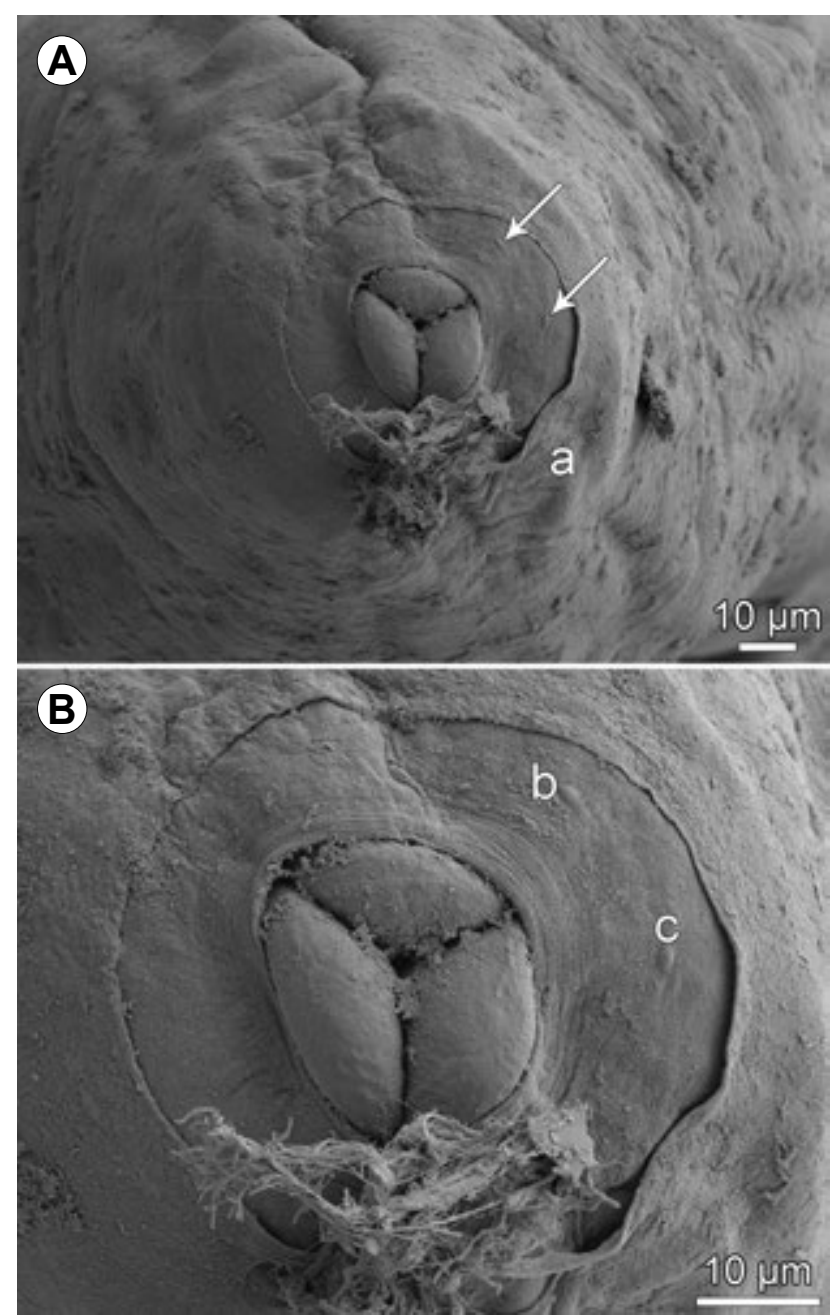

Fig. 13. Philometra sp. 2 from the subcutaneous tissue of the anterior-most head sinuses Hyporthodus niveatus (Valenciennes), scanning electron micrographs of gravid female. A - cephalic end, apical view (arrows indicate cephalic papillae of inner circle); B region of oral aperture, apical view. Abbreviations: a - submedian pair of cephalic papillae of outer circle; $b$ - submedian cephalic papilla of inner circle; $\mathrm{c}$ - lateral cephalic papilla of inner circle.

of The Elbow fishing grounds, $27.78333 ;-84.51666$, USA (collected 27 June 2017).

Prevalence and intensity: 1 fish infected/1 fish examined; 6 nematodes.

Deposition of voucher specimens: SNMNH USNM 1616444; IPCAS N-1211.
Other material: One additional female specimen was collected from the same host and infection site, but it was used for DNA extracting (data not presented) and is no longer available for examination.

Remarks. The gravid females of the present material are morphologically very similar to those of Philometra morii Moravec, Bakenhaster et Fajer-Ávila, 2010 and Philometra sp. of Moravec et al. (2010a), subcutaneous parasites of E. morio (Valenciennes) and Mycteroperca microlepis (Goode et Bean) (both Serranidae), respectively, in the northern Gulf of Mexico (Moravec et al. 2010a). Characteristic features of these three forms are the conspicuously expanded posterior half of the oesophageal gland, the oesophageal gland markedly extending anteriorly anterior to the level of the nerve ring and the cone-shaped caudal end of the body with two large lateral papilla-like caudal projections. Since also the biometrical data of these forms are, more or less, similar (Table 1) and could be considered to be within the intraspecific variability of a single species, it cannot be excluded that both the above-mentioned specimens from $M$. microlepis and the present specimens from $H$. niveatus belong to $P$. morii.

However, some Philometra spp. can be morphologically distinguished only by their males, whereas their conspecific females are indistinguishable, as found, for example, in some gonad-infecting species from serranid or lutjanid fishes (e.g., Moravec and Manoharan 2014a,b, Moravec et al. 2014, 2016a,c). On the other hand, $P$. rischta, for instance, a parasite of the host subcutaneous tissues, is reported from 14 species belonging to 10 genera of Palaearctic freshwater cyprinids (Moravec 2013). However, in those cases, the species identification was mostly based solely on females, whereas conspecific males were recorded and insufficiently described from only two host species (Molnár 1966, Kazakov 1989). Therefore, until conspecific males are described, both the present female specimens from subcutaneous tissues of $H$. niveatus and those from subcutaneous tissues of M. microlepis reported by Moravec et al. (2010a) should be designated as Philometra sp.

Besides the above-mentioned P. morii, Philometra sp. of Moravec et al., 2010 and the present Philometra sp. 2, the forms distributed in the Gulf of Mexico, there are an additional three forms of Philometra reported from the subcutaneous tissues or fins of serranid hosts in the Pacific region: $P$. pinnicola (Yamaguti, 1935) from the fins and 
the opercule of Epinephelus akaara (Temminck et Schlegel) from off Japan (Yamaguti 1935, 1941, Moravec et al. 2019); P. epinepheli Dewi et Palm, 2013 from the opercule of Epinephelus coioides (Hamilton) off Indonesia and northern Australia (Dewi and Palm 2013, Moravec and Diggles 2014b), and Philometra sp. from under the skin of Epinephelus summana (Forsskål) from off Okinawa, Japan (Hasegawa et al. 1991). The morphology of P. epinepheli and $P$. pinnicola is very different from that of the present Philometra sp. 2.

\section{DISCUSSION}

By the discovery of an additional two new species of Philometra, results of the present study extend the knowledge of the species composition of the fauna of philometrids parasitising marine fishes in the North-West Atlantic Ocean including the Gulf of Mexico, further confirming a considerable diversity of this group of parasites in the region. Additionally, taking into accout the high degree of host specificity of philometrids (Moravec et al. 2014, 2016a) and the fact that several host-specific philometrid species may infect different sites in the same host species in the same locality (Moravec et al. 2010a, Moravec and Barton 2018), and that a great many fish species living in this region have not yet been thoroughly examined for philometrids, many additional new species of philometrids are likely to be discovered and described during subsequent investigations.

Some philometrids designated only as Philometra sp. because of the absence of conspecific males may well prove to be new species. This may be the case of the specimens from the ovary of the needlefish Strongylura marina (Walbaum) (see Moravec and Bakenhaster 2012), or those from the subcutaneous tissues of groupers Mycteroperca microlepis and Hyporthodus niveatus (see Moravec et al. 2010a, present paper), as well as the individual reported in this paper as Philometra sp. 1 based on an insufficiently described single male specimen from the ovary of the snapper Rhomboplites aurorubens.

The present study confirms again the importance of male morphology for the species identification of philometrids, especially the detailed structure of the male caudal end, the gubernaculum and spicules, which require study by SEM.
Acknowledgements. We thank our FWRI colleagues Matt Bunting, John Davis, Sheri Parks, Scott Stahl and Hayden Menendez for their accommodation and leadership as chief scientists on the cruises that yielded specimens for study. Clark Gray, Eli Bastian, Maki Tabuchi and Kristina Deak were partners in processing hosts at sea or on land. Gene Alexander created Fig. 1. John Hunt and Alejandro Acosta hosted our work at the FWRI Marathon Laboratory. Greg Onorato promoted and supported inclusion of parasitologists on cruises. Theresa Cody and Susan Lowerre-Barbieri allocated financial and human resources necessary for completion of this work. Chip Collier (South Atlantic Fish Management Council) and Jim Locascio (Mote Marine Laboratory) provided critical field support for Warsaw Hole sampling, which also would not have been possible without the labours and skill of Captain Robert Schemmel and Austin Allende and Captain Steve Papen and Mike Hollingsworth of the F/V Sea-Ya and F/V Lagerhead, respectively. Thanks are also due to the Laboratory of Electron Microscopy, Institute of Parasitology, Biology Centre CAS, institution supported by the MEYS CR (LM2015062 Czech-BioImaging) and ERDF (No. CZ.02.1.01 /0.0/0.0/16_013/0001775), for their support with obtaining scientific data presented in this paper, and to Blanka Škoríková of the same Institute for help with the illustrations. This study was partly supported by the institutional support of the Institute of Parasitology, BC AS CR (RVO: 60077344). Funding for US research activities: support for Florida sampling was provided by the National Fish and Wildlife Foundation (NFWF) (40624, 45766, 50347,54269); National Oceanic and Atmospheric Administration (NOAA) (NA16NMF4350165, NA17NMF4540139, NFFN53001500009, NA15NMF4540104, NA18NMF4330240); the Pew Charitable Trusts; State of Florida saltwater recreational fishing license revenues; and the Wildlife and Sport Fish Restoration program (WSFR) (FL-F-F18AF00665, FL-F-F16AF00544, FL-F-F17AF00793). FWRI staff participation in manuscript production was supported with Federal Funds under WSFR award FL-F-F16AF00544. Any opinions, views, statements, findings, conclusions and recommendations expressed in this material are those of the authors; they do not necessarily reflect, and should not be interpreted as representing, the opinions, views, or policies of the NFWF, the Pew Charitable Trusts, the US Fish and Wildlife Service, WSFR, NOAA, the US Department of Commerce, or the US Department of the Interior. Nothing contained here constitutes an endorsement in any respect by the NFWF or any of the above-mentioned entities.

\section{REFERENCES}

Al-JAhDAli M.O. 2014: A pathological case caused by Philometra madai Quiazon, Yoshinaga \& Ogawa, 2008 (Nematoda: Philometridae) in the ovary of the onespot snapper fish Lutjanus monostigma (Teleostei, Lutjanidae) from the Red Sea. J. Adv. Biol. 6: 843-847.

Cavalcanti E.T.S., Takemoto R.M., Alves L.C., Chellappa S. 2010: First record of endoparasite Philometra sp. (Nematoda: Philometridae) in lane snapper Lutjanus synagris from the coast of Rio Grande do Norte, Brazil. Mar. Biodiv. Rec. 3: e93.

Crisp D.J., KLein V.L.M. 1973: Contribution to the knowledge of Philometra lateolabracis Yamaguti, 1935 [sic] (Nematoda, Filarioidea). Mem. Inst. Oswaldo Cruz 71: 481-483.

Dewi K., Palm H.W. 2013: Two new species of philometrid nematodes (Nematoda: Philometridae) in Epinephelus coioides
(Hamilton, 1922) from the South Bali Sea, Indonesia. Zootaxa 3609: 49-59.

Froese R., Pauly D. (Eds.) 2020: FishBase. World Wide Web electronic publication. http://www.fishbase.org, version 01/2020.

Ghanmi N., González-Solís D., Gargouri L. 2019: First description of the male and subgravid female of Philometra serranellicabrillae Janiszewska, 1949 (Nematoda: Philometridae), a gonad-infecting parasite of the comber Serranus cabrilla (Linnaeus) (Serranidae) off Tunisia. Syst. Parasitol. 96: 673-679.

Hasegawa H., Williams E.H., Bunkley-Williams L. 1991: Nematode parasites from marine fishes of Okinawa, Japan. J. Helminthol. Soc. Wash. 58: 186-197.

JanisZewSKa J. 1949: Some fish nematodes from the Adriatic Sea. Zool. Polon. 5: 7-30. 
KAZAKov V.E. 1989: [Studies on the population structure of Philometra rischta (Nematoda: Philometridae) from roach in lakes of Karelia.] In: Parasites of Freshwater Fishes of NorthWest Europe. Institute of Biology and Institute of Zoology, USSR Acad. Sci., Petrozavodsk, pp. 62-69. (In Russian.)

Linton E. 1907: Notes on parasites of Bermuda fishes. Proc. U.S Nat. Mus. 33: 85-126.

Martínez J.J., Ventosa L. 1982: Philometra lateolabracis (Nematoda: Philometridae), parásito de la biajaiba (Lutjanus synagris) (Osteichthyes: Lutjanidae) de Cuba. Poeyana 248: 1-6.

Measures L.N., Moravec F., Douglas S., Lair S. 2017: Philometra rubra (Nematoda: Philometridae) - first description of the male from striped bass (Morone saxatilis) and implications for re-introduction of an extirpated population. Can. J. Zool. 95: 345-352.

MolnÁr K. 1966: On some little-known and new species of the genera Philometra and Skrjabillanus from fishes in Hungary. Acta Vet. Acad. Sci. Hungr. 16: 143-158.

Molnár K., Fernando C.H. 1975a: Morphology and development of Philometra cylindracea (Ward and Magath, 1916) (Nematoda: Philometridae). J. Helminthol. 49: 19-24.

Molnár K., Fernando C.H. 1975b: Philometra kobuleji sp. n. (Nematoda: Philometridae). J. Helminthol. 49: 101-105.

Moravec F. 2006: Dracunculoid and Anguillicoloid Nematodes Parasitic in Vertebrates. Academia, Prague, 634 pp.

Moravec F. 2013: Parasitic Nematodes of Freshwater Fishes of Europe. Revised Second Edition. Academia, Prague, $601 \mathrm{pp}$.

MoraVec F., BaKenhaster M.D. 2012: New observations on philometrid nematodes (Philometridae) in marine fishes from the northern Gulf of Mexico and the Indian River Lagoon of Florida (USA), with first description of the male of Caranginema americana. J. Parasitol. 98: 398-403.

Moravec F., Bakenhaster M.D. 2013: Two new gonad-infecting philometrids (Nematoda: Philometridae) from the yellowedge grouper Hyporthodus flavolimbatus (Serranidae) and the great northern tilefish Lopholatilus chamaeleonticeps (Malacanthidae) in the northern Gulf of Mexico. Syst. Parasitol. 86: 113-123.

Moravec F., Bakenhaster M.D., Adams D.H. 2016b: Two new species of Philometra Costa, 1845 (Nematoda: Philometridae) from Mycteroperca spp. (Serranidae) in the North-West Atlantic and northern Gulf of Mexico, USA. Syst. Parasitol. 93: 479-491.

Moravec F., Bakenhaster M.D., De Buron I. 2013: A new gonad-infecting species of Philometra (Nematoda: Philometridae) from the Atlantic Spanish mackerel Scomberomorus maculatus (Scombridae) off the Atlantic coast of Florida and South Carolina. J. Parasitol. 99: 290-296.

Moravec F., Bakenhaster M.D., Fajer-Ávila E.J. 2010a: New philometrids (Nematoda, Philometridae) from head tissues of two serranid fishes (Epinephelus morio and Mycteroperca microlepis) off Florida, northern Gulf of Mexico. Acta Parasitol. 55: 359-368.

Moravec F., Bakenhaster M.D., Fajer-Ávila E.J. 2014: Three new gonad-infecting species of Philometra (Nematoda: Philometridae) parasitic in Lutjanus spp. (Lutjanidae) in the northern Gulf of Mexico off Florida, USA. Folia Parasitol. 61: 355-369.

Moravec F., Bakenhaster M.D., Leone E.H. 2017a: Redescription of Philometra margolisi Moravec, Vidal-Martínez et Aguirre-Macedo, 1995 (Nematoda: Philometridae), a gonad-infecting parasite of the red grouper Epinephelus morio (Serranidae) in the Gulf of Mexico. Acta Parasitol. 62: 412-421.

Moravec F., Barton D.P. 2018: New records of philometrids (Nematoda: Philometridae) from marine fishes off Australia, including description of four new species and erection of Digitiphilometroides gen. n. Folia Parasitol. 65: 005.

Moravec F., De Buron I. 2013: A synthesis of our current knowledge of philometrid nematodes, a group of increasingly important fish parasites. Folia Parasitol. 60: 81-101.

Moravec F., De Buron I., Roumillat W.A. 2006a: Two new species of Philometra (Nematoda: Philometridae) parasitic in the perciform fish Cynoscion nebulosus (Sciaenidae) in the estuaries of South Carolina, USA. Folia Parasitol. 53: 63-70.

Moravec F., Chaabane A., Justine J.-L., Neifar L. 2016c: Two gonad-infecting species of Philometra (Nematoda: Philometridae) from groupers (Serranidae) off Tunisia, with a key to Philometra species infecting serranid gonads. Parasite 23: 8.

Moravec F., Chaabane A., Neifar L., Gey D., Justine J.-L. 2016a: Descriptions of Philometra aenei $\mathrm{n}$. sp. and P. tunisiensis n. sp. (Nematoda: Philometridae) from Epinephelus spp. off Tunisia confirm a high degree of host specificity of gonad-infecting species of Philometra in groupers (Serranidae). Syst. Parasitol. 93: 115-128.

Moravec F., Chaabane A., Neifar L., Gey D., Justine J.-L. 2017b: Species of Philometra (Nematoda, Philometridae) from fishes off the Mediterranean coast of Africa, with a description of Philometra rara n. sp. from Hyporthodus haifensis and a molecular analysis of Philometra saltatrix from Pomatomus saltatrix. Parasite 24: 8.

Moravec F., Diggles B.K. 2014a: Two new gonad-infecting species of Philometra Costa, 1845 (Nematoda: Philometridae) from marine fishes off the northern coast of Australia. Syst. Parasitol. 89: 33-44.

Moravec F., Diggles B.K. 2014b: Philometrid nematodes (Philometridae) from marine fishes off the northern coast of Australia, including three new species. Folia Parasitol. 61: 37-54.

Moravec F., Diggles B.K. 2015: A new gonad-infecting species of Philometra, P. barnesi sp. n. (Nematoda: Philometridae), from the marine fish Pomadasys argenteus (Haemulidae) off the northern coast of Australia. Parasitol. Res., 114: 4121-4126.

Moravec F., Fajer-Ávila E.J., Bakenhaster M.D. 2010b: Philometra floridensis sp. n. (Nematoda: Philometridae) from the ovary of red drum Sciaenops ocellatus (Osteichthyes: Sciaenidae) off the coast of Florida,USA. J. Helminthol. 84: 49-54.

Moravec F., Justine J.-L. 2005: Two species of Philometra (Nematoda, Philometridae) from serranid fishes off New Caledonia. Acta Parasitol. 50: 323-331.

Moravec F., Justine J.-L. 2008: Some philometrid nematodes (Philometridae), including four new species of Philometra, from marine fishes off New Caledonia. Acta Parasitol. 53: 369-381.

Moravec F., Justine J.-L. 2011: Two new gonad-infecting Philometra species (Nematoda: Philometridae) from the marine fish Lutjanus vitta (Perciformes: Lutjanidae) off New Caledonia. Folia Parasitol. 58: 302-310.

Moravec F., Manoharan J. 2014a: Gonad-infecting species of Philometra (Nematoda: Philometridae) from groupers Epinephelus spp. (Osteichthyes: Serranidae) in the Bay of Bengal, India. Acta Parasitol. 59: 596-605.

Moravec F., Manoharan J. 2014b: Two new gonad-infecting species of Philometra (Nematoda: Philometridae) parasitic in Lutjanus spp. (Osteichthyes: Lutjanidae) in the Bay of Bengal, India. Parasitol. Res. 113: 3299-3307.

Moravec F., Manoharan J. 2016: Philometra dissimilis n. sp. from the ovary of Johnius belangerii (Sciaenidae) and other new records of philometrids (Nematoda: Philometridae) from fishes of the Bay of Bengal, India. Helminthologia 53: 133-141.

Moravec F., Nagasawa K., Nitta M., Tawa A. 2019: New records of philometrids (Nematoda: Philometridae) from marine fishes off Japan, including description of Philometra kidakoi sp. n. and Congerinema japonicum gen. et sp. n. Folia Parasitol. 66: 021 .

Moravec F., Ternengo S., Levron C. 2006b: Three species of Philometra (Nematoda: Philometridae) from marine fishes off Corsica, France. Acta Parasitol. 51: 111-118.

Moravec F., Vidal-Martínez V.M., Aguirre-Macedo L. 1995: Philometra margolisi n. sp. (Nematoda: Philometridae) from the gonads of the red grouper, Epinephelus morio (Pisces: Serranidae), in Mexico. Can. J. Fish. Aquat. Sci. 52 (Suppl. 1): 161-165.

ODENING K. 1976: Conception and terminology of hosts in parasitology. Adv. in Parasitol. 14: 1-93. 
Quiazon K.M.A., Yoshinaga T., Ogawa K. 2008: Taxonomical study into two new species of Philometra (Nematoda: Philometridae) previously identified as Philometra lateolabracis (Yamaguti, 1935). Folia Parasitol. 55: 29-41.

ReEs G. 1970: Some helminth parasites of fishes of Bermuda and an account of the attachment organ of Alcicornis carangis MacCallum, 1917 (Digenea: Bucephalidae). Parasitology 60: 195221

SAFMC (South Atlantic Fishery Management Council) 2020: https://safmc.net/spawning-special-management-zones-florida/. Accessed 18 March 2020.

Sokolov S.G., KAzAkov B.E. 2007: [Redescription of the male of Philometra rischta Skrjabin, 1923 (Nematoda: Dracunculoidea:
Philometridae) and notes on the female morphology of this species.] Zool. Bespozvonoch. 4: 151-160. (In Russian with Engl. abstract.)

Sokolov S.G., Kazakov B.E. 2008: [On the morphology and taxonomic status of some species of the genus Philometroides (Nematoda, Philometridae).] Zool. Zh. 87: 1420-1424. (In Russian with Engl. abstract.)

Yamaguti S. 1935: Studies on the helminth fauna of Japan. Part 9. Nematodes of fishes, 1. Jpn. J. Zool. 6: 337-386.

Yamaguti S. 1941: Studies on the helminth fauna of Japan. Part 33. II. Nematodes of fishes. Jpn. J. Zool. 9: 343-396.

Cite this article as: Moravec F., Bakenhaster M.D., Switzer T.S. 2020: New records of Philometra spp. (Nematoda: Philometridae) from marine perciform fishes off Florida, USA, including descriptions of two new species. Folia Parasitol. 67: 017. 